\title{
Doctors, Miners, and Black Lung: A transatlantic comparison of organized medicine's role in the fight for black lung recognition in West Virginia and Wales
}

Mollie M. Cecil MD

West Virginia University, mmccart7@mix.wvu.edu

Follow this and additional works at: https://researchrepository.wvu.edu/etd

Part of the Appalachian Studies Commons, History of Science, Technology, and Medicine Commons, Labor History Commons, and the United States History Commons

\section{Recommended Citation}

Cecil, Mollie M. MD, "Doctors, Miners, and Black Lung: A transatlantic comparison of organized medicine's role in the fight for black lung recognition in West Virginia and Wales" (2021). Graduate Theses, Dissertations, and Problem Reports. 8093.

https://researchrepository.wvu.edu/etd/8093

This Thesis is protected by copyright and/or related rights. It has been brought to you by the The Research Repository @ WVU with permission from the rights-holder(s). You are free to use this Thesis in any way that is permitted by the copyright and related rights legislation that applies to your use. For other uses you must obtain permission from the rights-holder(s) directly, unless additional rights are indicated by a Creative Commons license in the record and/ or on the work itself. This Thesis has been accepted for inclusion in WVU Graduate Theses, Dissertations, and Problem Reports collection by an authorized administrator of The Research Repository @ WVU. For more information, please contact researchrepository@mail.wvu.edu. 
Doctors, Miners, and Black Lung: A transatlantic comparison of organized medicine's role in the fight for black lung recognition in West Virginia and Wales

Mollie M. Cecil, MD

Thesis submitted to the Eberly College of Arts and Sciences at West Virginia University in partial fulfillment of the requirements for the degree of

Master of Arts in History

\section{Kenneth Fones-Wolf, Ph.D, Co-Chair Jessica Wilkerson, Ph.D, Co-Chair \\ Robert Blobaum, Ph.D \\ Department of History}

\section{Morgantown, WV}

2021

Keywords: Black Lung, United Mine Workers of America, American Medical Association, British Medical Association, West Virginia, Wales

Copyright 2021, Mollie M. Cecil, 


\begin{abstract}
Doctors, Miners, and Black Lung: A transatlantic comparison of organized medicine's role in the fight for black lung recognition in West Virginia and Wales
\end{abstract}

\title{
Mollie M. Cecil, MD
}

Black lung disease is a crippling occupational lung disease experienced by coal miners throughout the world. However, this disease was not always recognized by the medical profession and required significant efforts on the part of miners' unions to force mainstream recognition. The historiography on the subject is limited, especially with respect to the relationship between organized medicine and organized labor. This work further explores this relationship, particularly how this relationship differed between the parties in Wales and in West Virginia. In doing so, it portrays a more detailed picture of the fight for black lung recognition as well as highlights the different relationships between medicine and miners in the two regions. 
INTRODUCTION

CHAPTER ONE: RELATIONSHIPS BETWEEN MINERS AND THEIR PHYSICIANS

Quality of Care and the Fifth Freedom in West Virginia

British Physicians and their Miner Patients

24

CHAPTER TWO: THE BRITISH STRUGGLE FOR RECOGNITION

CHAPTER THREE: WEST VIRGINIA PHYSICIANS AND BLACK LUNG RECOGNITION 


\section{Introduction}

In the depths of the Great Depression, B.L. Coombes, a Welsh coal miner, went to his neighborhood pub. Coal production had fallen drastically as a result of the global economic disaster, and mines were either running at decreased capacity or not at all. The topic of conversation that day was the terrible lung disease afflicting many of the miners. Two miners required help to climb the steps of the local library. One struggles breathlessly to chapel now that he realized he was going to die soon, before he was even 30. Another had lungs so scarred that during the autopsy, the doctors were said to have blunted their chisels when attempting to dissect his lungs. 1

Twenty years later, a young man growing up in West Virginia noticed his father's worsening respiratory problems. No one knew exactly what was wrong with him, but he experienced "unshakable colds" and "wracking coughs" that kept him up at night. When he was still a relatively young man, only middle-aged, his son noticed that his dad couldn't even cross a street without gasping for air. ${ }^{1}$

Both of these men were miners experiencing the epidemic of black lung disease firsthand. Both men saw their friends, neighbors, and relatives slowly lose their ability to breathe after years of inhaling toxic coal dust as miners. Both men waited for the day when their own breath would grow short, their coughs would start, and their lungs would fail. Both men worried greatly about what this would mean for their ability to provide for their family. However, they lived thousands of miles apart, separated by an ocean. The first man, B.L. Coombes, was a miner living in the South Wales coalfields in the first half of the twentieth century. The second man,

\footnotetext{
${ }^{1}$ BL Coombes, These Poor Hands: The Autobiography of a Miner Working in South Wales. (London: V. Gollancz, 1939), 235-236.

${ }^{1}$ Duane Lockard, Coal: A Memoir and a Critique (Charlottesville: University Press of Virginia, 1998$), 75$.
} 
Duane Lockard, grew up in the West Virginia coalfields, working in mines to pay for his schooling, before eventually becoming a professor at Princeton University. They were both working men, with the same human lungs that were susceptible in the same way to the same diseases. However, by 1943 Coombes no longer had to worry about his family starving if he were debilitated by occupational lung disease. Great Britain had passed legislation ensuring that miners afflicted by the disease would receive just compensation and assistance, since they could no longer work. Lockard, and his father which he discusses, did not have that same peace of mind. Lockard's father died of black lung before it was recognized, lacking treatment or compensation for his fatal illness. It was not until 1969, four years after his death, that his illness was recognized throughout the United States.

Black lung disease, or coal workers' pneumoconiosis (CWP), is a lung disease caused by the inhalation of coal dust into the lungs. ${ }^{2}$ The coal dust accumulates in the airways and produces a spectrum of abnormal changes in the lungs. These changes could be as mild as "anthracosis", which is simple coal dust deposition without any other damage to the lungs. However, the dust can also trigger inflammation in the lungs, which can manifest in varying degrees of breathing problems. At its worst, coal dust can trigger massive scarring in the lungs, or pulmonary massive fibrosis (PMF) which is a rapidly progressive and often fatal disease. There is usually a latency period between exposure and the onset of symptoms, although this latency period varies between individuals and coalfields. ${ }^{3}$ Miners who suffer from it experience the symptoms of other chronic lung disease: frequent coughing, difficulty breathing during

\footnotetext{
2 "Black lung" is the colloquial term for the disease and commonly used among lay and medical professionals in the United States. "Coal workers' pneumoconiosis" is the official medical diagnostic term for the disease, and more often used in Great Britain and in medical journal articles. "Black lung" will be used throughout this work, but CWP will often be used in the medical literature and in quotes from Great Britain.

${ }^{3}$ Jennifer Perret et al., "Coal Mine Dust Lung Disease in the Modern Era," Respirology 22, no. 4 (2017): pp. 662670 .
} 
exertion, and eventually the inability to breathe without supplemental oxygen. When they cough, they often bring up thick, black, tar-like sputum which is an aggregate of coal dust and mucus caused by the inflammation in the airways. Black lung disease can occur alongside other respiratory illnesses, such as those caused by smoking or tuberculosis. It can also occur at the same time as lung damage caused by the inhalation of silica fibers, which cause a separate and distinctive series of changes in the lungs. In many mining areas, especially those with hard coal, the rock contains a high percentage of silica as well as coal. The mining process releases these silica fibers and they are inhaled in addition to the coal dust. However, black lung and silicosis can occur independently of each other.

The first official medical report of black lung disease occurred in 1806, when a French Physician reported on a "melanosis of the lungs" among French coal miners. In 1813, the disease was reported in the British medical literature. ${ }^{4}$ In 1943 the British government, colliery owners, and physicians recognized the existence of this disease as an entity separate from silicosis. Despite this lengthy road to recognition, British labor, medicine, and government was twenty years ahead of recognizing the disease compared to their American counterparts. It was not until 1969 that the U.S. federal government recognized the disease. In Britain, after achieving recognition, the unions and organized medicine worked to push the coal industry (both before and after nationalization) to enact dust suppression measures to prevent the development and worsening of the disease among miners. This was accomplished with the backing of a Labour government with a strong commitment to interwar and postwar societal change. This cooperation

\footnotetext{
${ }^{4} \mathrm{~K}$. Donaldson, WA Wallace, and C Henry, "James Craufurd Gregory, $19^{\text {th }}$ century Scottish physicians, and the link between occupation as a coal miner and lung disease", Journal of the Royal College of Physicians of Edinburgh no. 47 (2017): 296-302.
} 
of organized medicine, organized labor, and a leftist government was also key in the establishment of the National Health Service.

Today, there is no question among the international medical community that black lung disease is a distinct disease process directly linked to employment in coal mines. This was not always the case. The coal industry steadily grew for centuries, exploding along with manufacturing in the Industrial Revolution, and more and more workers were employed in the mines. In all of the mining regions of the world, it overtook farming as the chief occupation. The health problems of the miner could not be ignored, and it was common knowledge that miners suffered injuries and death due to accidents such as roof falls and explosions. However, while the miners themselves recognized that they were also suffering from breathing difficulties in the mines, the industry, their governments, and the medical community did not recognize that a problem existed. This was devastating for two reasons. For one, this meant that steps were not taken to improve safety in the mines and prevent the disease from developing. Second, this meant that when men inevitably became disabled as a result of black lung disease, they were unable to collect workmen's compensation benefits to make up for their lost wages. Men suffering from the early stages of the disease had no choice but to keep working until they were physically unable to, despite the ongoing damage to their lungs. Men who were unable to work faced starvation for themselves and their families.

Workmen's compensation laws were developed internationally to ensure that workers who were injured as a direct result of their occupations received compensation to make up for their lost wages. However, these laws did and continue to hinge upon specific diagnostic criteria for diseases and proof that the disease occurred as a direct result of employment. For some illnesses, this is easy. If a roof falls on a man in the mines, shattering his leg, there is no question 
that his injury was a direct result of the roof fall and his job. However, for insidious diseases such as black lung the link between cause and effect is not as immediate. For black lung to be recognized as a disease eligible for compensation, it had to satisfy multiple criteria. First, it had to be recognized as a distinct disease which could be objectively diagnosed by medical professionals. Second, it had to be proven that specific working conditions caused the disease. This meant that until the medical community accepted it as a distinct disease entity, it did not officially exist. If it did not officially exist, then there was no way to prove that exposure to coal dust in the mines caused it.

Silicosis, the lung disease caused by inhaling silica fibers, was recognized by governments around the turn of the $20^{\text {th }}$ century. After becoming an officially accepted disease process in the minds of medical professionals, miners and the government worked to determine how much silica exposure could be reasonably expected to cause silicosis. To be eligible for compensation for silicosis, miners had to show that they were experiencing signs and symptoms of the disease and that they had worked in mines with the threshold of silica needed to trigger the disease. For miners, silicosis was the only officially recognized lung disease. If a miner developed breathing problems but he did not work in a mine that met the silicosis criteria, his disease was automatically ruled to be non-occupational. This meant that he could not collect compensation and he would have to continue working or resort to begging and charity to provide for himself and his family.

We accept now that silicosis and black lung are a known occupational hazard of coal mining. Human lungs have not changed over the centuries, nor has the fundamental composition of rock in which coal is found. Miners have always been exposed to the damaging effects of coal dust. So, why did it take until 1943 in Great Britain and 1969 in the United States for there to be 
national recognition of black lung disease? Furthermore, why was there such a delay in recognition between the two countries? Finally, what does the struggle for black lung tell us about the relationships between organized medicine, miners, and their governments?

Despite its important role in these relationships and in the lives of miners, black lung is not a topic that has had widespread scholarly coverage. Despite the significance that recognition of black lung had for miners in British coal fields, little has been written about it by historians. The only comprehensive history is Arthur McIvor's and Ronald Johnston's work, Miners' Lung: A History of Dust Disease in British Coal Mining. ${ }^{5}$ Miners' Lung lays out the history of CWP and the battle for its recognition. Drawing from a rich oral history project conducted in the Scottish coal fields, the authors examined the roles of masculinity, the dissemination of medical knowledge, and the lived experiences of miners with the disease. They also examined the role of medical professionals and the unions in obtaining recognition for black lung. This work stands out in utilizing a large number of Scottish sources, as the vast majority of writings about the British coal fields focus on the Welsh fields.

Miners' Lung explores the black lung battle with the most detail and has provided the most expansive view of the role of the key organizations in the fight, although a detailed analysis is only conducted of the actions of the unions, with little time spent on organized medicine. No other works have examined the situation in detail, although several works have studied the parties involved during the time period. Chris Williams has written extensively on the political history of the Welsh coal fields in this time period. ${ }^{6}$ Other works, such as Manchester University

\footnotetext{
${ }^{5}$ Arthur McIvor and Ronald Johnston. Miners' Lung: A History of Dust Disease in British Coal Mining. (London: Ashgate Publishing, 2007)

${ }^{6}$ Chris Williams. Capitalism, Community, and Conflict: The South Wales Coalfield, 1898-1947. (Cardiff: University of Wales Press, 1998). See also Democratic Rhondda: Politics and Society, 1885-1951. (Cardiff: University of Wales Press, 1996), and The Labour Party in Wales: 1900-2000, edited by Duncan Tanner, Chris Williams, and Deian Hopkin. (Cardiff: University of Wales Press, 2000).
} 
Press's series on disability in Industrial Britain, have focused on the relationship of organized medicine with miners. What is missing from the historiography is a detailed analysis of the role of organized medicine in the black lung fight, as well as an analysis of the interaction between organized medicine and organized labor in the time period.

Historiography of the United States battle tends to follow the same trends as in the British example. Conventional historiography on this topic has focused heavily on the activities of the rank-and-file UMWA members who embarked on a rogue crusade for black lung compensation. As a result, the current narrative of the black lung disease recognition movement is largely a labor history narrative. The actions of the Black Lung Association — the association formed by miners, their wives, and their widows to fight for compensation — were truly impressive and ultimately effective. Discontent over a variety of issues had been building within the membership of the United Mine Workers of America (UMWA), and the Black Lung Association (BLA) was a symptom of this larger pathology. Thus, it is an important story to tell and a flashpoint in the history of the UMWA. Histories of the UMWA and this period in Appalachian history appropriately devote attention to this labor movement. Jerry Bruce Thomas's Appalachian Reawakening and Ronald Eller's Uneven Ground are prime examples, and these works provide excellent insight into this period in Appalachian and UMWA history. ${ }^{7}$ An additional monograph about the history of the UMWA Health and Retirement Fund, Richard Mulcahy's $A$ Social Contract for the Coal Fields, discusses the black lung issue. ${ }^{8}$ It is not the focus of his work, but his work traces the establishment and history of the Fund, which provided universal healthcare to

7 Ronald Eller, Uneven Ground: Appalachia Since 1945. (Lexington: University Press of Kentucky, 2008) and Jerry Bruce Thomas, An Appalachian Reawakening: West Virginia and the Perils of the New Machine Age, 1945-1972 (Morgantown: West Virginia University Press, 2010).

${ }^{8}$ Richard Mulcahy, A Social Contract for the Coal Fields: The Rise and Fall of the United Mine Workers of America Welfare and Retirement Fund, (Knoxville: University of Tennessee Press, 2000). 
miners and their families free of charge. The development and operations of the Fund were contentious and caused a great deal of ill will between the UMWA and organized labor, and Mulcahy's work does an excellent job exploring these conflicts.

What has been covered to a far less extent is the reaction of the medical community to this drama, and the understanding by the medical community of the disease process. In Black Lung: Anatomy of a Public Health Disaster, Alan Derickson traces the history of black lung from the earliest reports of the disease, in Ancient Greece, to the passage of federal black lung benefits law at the end of $1969 .{ }^{9}$ This is by far the most comprehensive work on the subject to date. In his book, Derickson asserts that widespread complacency had developed in the medical community as a result of the conflicting pulls of coal miner health and coal industry interests. ${ }^{10}$ There is no question that the coal industry had a strong, vested interest in denying the existence of any disease for which it would be held financially accountable. Derickson further asserts that the medical community viewed physicians contracted with the UMWA Welfare and Retirement Fund (Fund) as "dangerous renegades," and credits Dr. Lorin Kerr of the Fund for nearly singlehandedly driving US interest in black lung. ${ }^{11}$ These assertions do touch on an underlying friction between the mainstream medical establishment and the Fund, but also discredits the efforts of many local physicians in coal mining communities to learn more about black lung.

No comparative studies exist currently examining the recognition fight in the British and the American coalfields. There was transatlantic communication between both labor and the medical community, and the leaders of medicine and labor were familiar with the issues faced by their counterparts across the ocean. While they were linked by this communication, around

9 Alan Derickson, Black Lung: Anatomy of a Public Health Disaster, (Ithaca: University of Cornell Press, 1998) 10 Derickson, xiii. 11 Derickson, 132. 
World War II the political, medical, and labor systems of the two countries diverged significantly. The relationships forged in the British coalfields between medicine, miners, and government directly contributed to the creation of the British welfare state, especially the National Health Service (NHS). Conversely, these same relationships prevented the development of universal healthcare in America.

This thesis examines and compares the fight for black lung recognition in the United States and in Great Britain. It focuses on the medical community in each country, focusing on relationships with labor and dissemination of medical knowledge. This approach allows new interpretations of the black lung fight, especially in West Virginia. Instead of rogue doctors and rogue miners uncovering a vast conspiracy, in West Virginia one sees a fundamentally different relationship between medicine and labor and gains a new understanding of how medical information was disseminated during this time period. To accomplish this, a wide variety of sources have been engaged. First, the medical literature of each country during their respective debates over black lung was examined. These scientific journal articles illustrate the information about black lung that was disseminated to individual physicians in each country. It also illustrates the relative priorities which American and British physicians placed on the subject of black lung. For this, the major national journals were examined, namely the British Journal of Medicine (BJM), the Journal of the American Medical Association (JAMA), the British Journal of Industrial Medicine (BJIM), and the American Journal of Industrial Medicine. In addition, the West Virginia Medical Journal (WVMJ) was studied to ascertain any differences between the national, state, and rank-and-file priorities which organized medicine placed on black lung and labor relationships in the United States. As the official journal of the West Virginia State Medical Association (WVSMA, the state-level body of the AMA), the WVMJ documents 
everything from important medical research articles to the activities of the county societies and their auxiliaries. West Virginia coalfield newspaper accounts help to augment this examination by providing another viewpoint of both miners and doctors at the time.

Other important sources for this work were the proceedings of the national conventions for organized labor and organized medicine in the two countries. Proceedings of the UMWA and the AMA's national bodies were examined, as well as the minutes (via the BJIM) and speeches of the National Union of Mineworkers in Great Britain. As with the medical literature, these sources illustrate the priorities of the national bodies of labor and medicine during this time period. The UMWA Proceedings also show the priorities of the rank-and-file miners, as it contains verbatim resolutions proposed by local union branches. Finally, it illustrates the degree of concurrence — or dissent—among miners. For instance, numerous similar and identical proposals relating to free choice of physician for miners were proposed year after year, showing that this was a common concern for miners all over the United State.

The archives of the United Mine Workers of America Health and Welfare Fund (hereafter referred to as the Fund), were an immensely important resource for this study. This large archive collection includes the personal correspondence of Fund administrators, reports and studies on the internal workings of the Fund, and administrators' personal records regarding the AMA and other large professional societies. As will be discussed later, the Fund was an ambitious healthcare delivery system created by the UMWA to ensure access to high quality healthcare for miners and their dependents. It is an invaluable resource for studying healthcare in the American coalfields.

Finally, a large body of secondary literature was studied to examine the development of modern medicine in each country, with a focus on how medicine interacted with miners. On this 
topic, the British and American historiography have diverged considerably. Many monographs and essay collections published by British historians examine the complex relationship between doctors and miners in the British coalfields, particularly Wales. The development of modern British medicine is also frequently discussed in the context of its relationship with miners and the industrialization of Great Britain. This same topic has not been studied or examined in America. The development of American medicine is explored relatively isolated from the changing occupational landscape of America.

The geographical settings for this work are both broad and targeted, with focuses on two very important regions. It is broad in that it is a transatlantic, international comparison of the national-level policies of medicine, government, and labor. However, many sources focus on just two regions: West Virginia and Wales. West Virginia was the frontline for black lung recognition in the United States. Its miners and its physicians overwhelmingly led the charge for the disease to be taken seriously by local, state, and federal governments and medicine. Welsh miners and the Welsh coalfields had the same important role in Great Britain. Black lung was disproportionately present in South Wales mines, and the Labour Party was born in these same coalfields. Therefore, to tell the story of black lung in America one must focus on West Virginia. To tell the story of black lung in Great Britain, one must correspondingly focus on Wales.

This work assesses each country and region separately by section. Chapter one explores the relationships between miners and their coalfield doctors, as well as between the highest levels of organized medicine and organized labor. It focuses first on America, particularly disputes over free choice of physician, with attention given to West Virginia communities. It then turns its attention to Great Britain and similarly focuses on Wales. Chapter two studies the fight for black lung recognition in Great Britain, focusing on the efforts of the British medical 
establishment, the Labour Party, and the South Wales miners. Chapter three explores the fight for black lung recognition in the United States by focusing on the battle waged in West Virginia. The conclusion examines additional areas of inquiry on this topic and the new importance of this topic in the COVID-19 pandemic era. 


\section{Chapter One: Relationships between miners and their physicians}

\section{Quality of Care and the Fifth Freedom in West Virginia}

To fully understand the history of the fight for black lung recognition, it is necessary to study the relationships between coalfield physicians and miners as well as the relationship between the upper levels of organized medicine and the upper levels of miners' unions. These relationships were often fraught with distrust and tension. As with organized labor, the motivations and beliefs of the rank-and-file members of the medical profession did not always perfectly align with that of their leadership. However, while the American medical profession tended towards anti-labor attitudes with some rank-and-file exceptions, the British medical profession was more labor-friendly due to its longstanding relationship with miners. This tendency was true of one of America's most important coal regions-Appalachia.

As with many popular perceptions of the region, for decades those outside of the region — especially the East Coast elites—had a low opinion of Appalachian medicine. They viewed the Appalachian medical establishment as being backward and devoid of all scientifically-based treatment and diagnosis. ${ }^{1}$ The medical community played a large role in this, especially at the turn of the twentieth century. Progressive-era female reformers, such as Mary Breckinridge, had a vested interest in emphasizing and exaggerating the medical problems of Appalachia. This ensured that urban donors would continue funding their public health projects by emphasizing Appalachia as a place of desperate need and ignorance. ${ }^{2}$ Appalachian physicians

\footnotetext{
${ }^{1}$ Mulcahy, 61 .

${ }^{2}$ Melanie Beals Goan, Mary Breckinridge: The Frontier Nursing Service and Real Health in Appalachia (Chapel Hill: The University of North Carolina Press, 2008), 251.
} 
at the time of industrialization certainly lagged behind their urban peers in medical knowledge, but as Sandra Barney points out in Authorized to Heal, another large issue was the major lack of physicians in the area at the time. In 1886, there were only 222 physicians in Central Appalachia. By 1917, that number had increased to 636 . The coal industry brought immense changes to the region and increased access to physicians was one of these. ${ }^{3}$ Additionally, the physicians hired by the coal companies were a different sort of doctor. The older, established coalfield physicians rarely had extensive formal training. The coal companies brought in young physicians making use of reformed medical education, and this became an attractive recruitment tool for many miners. ${ }^{4}$ By the 1940s, the majority of Appalachian citizens and coal miners had at least some access to a trained physician. Folk medicine still played a role, but overall citizens looked towards allopathic physicians to care for them. ${ }^{5}$

While on its surface this increased access seemed like a wonderful benefit to the miners, it caused new tensions to form between coalfield physicians and their patients. For one, these physicians replaced older local physicians with whom the miners had long relationships and cultural kinship. Second, the miners were justifiably concerned about the impartiality of a physician employed by a coal company. Finally, the aggressive fee structure and demand for payment from their patients, often prior to rendering care, was an unwelcome change to medical habits of the coalfields. ${ }^{6}$ Miners were concerned about the quality of medical care they received, and they were also very concerned about perceived bias in physicians. Specifically, they wanted

\footnotetext{
${ }^{3}$ Sandra Barney, Authorized to Heal: Gender, Class, and the Transformation of Medicine in Appalachia, 18801930, (Chapel Hill: The University of North Carolina Press, 2000), 34.

${ }^{4}$ Barney, 29.

5 "Allopathic" refers to physicians who have trained in a traditional medical school and received the title of M.D. Today, physicians can be allopathic or osteopathic doctors (DOs), and both receive the same high levels of training and education with differences mainly in philosophy of treatment approaches rather than the science of their medicine. However, during the period covered in this thesis, osteopathy was still considered a fringe, alternative medicine without standardized training.

${ }^{6}$ Barney, 33 .
} 
to be able to choose the doctors the coal companies would contract for their care and they wanted to ensure that coalfield physicians would treat them impartially in workmen's compensation cases. The national convention of the United Mine Workers of America regularly had numerous resolutions by delegates and speeches by officers focused on these issues. One such 1944 resolution, from Local Union \#7905 in Gary, WV sums up the miners' typical attitudes about the company physicians:

"Whereas, The coal companies who hire the doctors, and paid by the employees, are used against the employes [sic] to prevent them from receiving compensation and insurance; therefore be it Resolved, That a law passed granting the employes [sic] the right to employ their doctor, thus he may not be used to discriminate against the ones who pay him."7

Other concerns voiced at conferences dealt with non-company physicians having financial or other reasons to underrepresent miner disease and injury. Still other complaints involved doctors refusing to make house calls (standard medical practice at the time), refusing to treat miners in a timely fashion, and having only limited hours for treatment of miners. All of these actions served to restrain the care that miners and their families could receive in their communities. ${ }^{8}$ Miners proposed and passed dozens of resolutions condemning the behavior of coalfield physicians during each convention from the 1930s to the 1950s. The overwhelming messages in these resolutions were that miners believed their company doctors were too expensive, not available for care, and biased in their treatment of miners and their families.

\footnotetext{
${ }^{7}$ Proceedings of the UMWA Constitutional Convention, 1944, 352. Hereafter referred to by "UMWA Proceedings" and the corresponding year.

${ }^{8}$ UMWA Proceedings, 1946, 338.
} 
The UMWA, independent of miners' resolutions, was also concerned with the health of mining communities. In the 1930s, they established teams to investigate and monitor the health of miners. As early as 1938 they reported to members about the health issues faced in the coalfield communities. Miners experienced an increased rate of respiratory and degenerative diseases and lived about seven years less than those in other occupations. Thus, occupational health programs were important to improve the lives of miners. They actively requested that the United States Public Health Service begin investigating working conditions in the mines as well as regulating and enforcing practices to improve industrial health. ${ }^{9}$ The preliminary reports created by these investigations added to the mistrust miners had for physicians in their communities. Not only did miners believe that their local physicians could not be trusted to care for them impartially and professionally, but they also could not be trusted to ensure the public health of the coalfields.

Miners' trust in the abilities of local physicians took a further hit when the Boone Report was released in 1947. Officially titled A Medical Survey of the Bituminous Coal Industry: Report of the Coal Mines Administration, this report colloquially carried the name of the Rear Admiral responsible for conducting the medical survey that produced it. ${ }^{10}$ It was an appalling revelation of the poor health conditions in the bituminous coal fields of the country. The Boone report laid blame equally for the health problems, stating:

"Regardless of the total amount, the fact remains that coal-mining communities are not receiving a proportion share of the Funds being spent and of the public health services already available. Several reasons discussed....are: Too many local health

\footnotetext{
${ }^{9}$ UMWA Proceedings, $1938,74$.

${ }^{10}$ United States Coal Mines Administration, A Medical Survey of the Bituminous-Coal Industry: Report of the Coal Mines Administration, (Washington: U.S. Government Printing Office, 1947). "Boone Report."
} 
departments...are unable to render services in the less congested areas...Public health workers are reluctant to extend services and programs into company-owned communities. Coal miners have not demanded programs in public health and sanitation. Coal-mine operators have not encouraged and arranged for the establishment and maintenance of public health programs. Physicians associated with coal mines have not promoted public health programs, and they have been indifferent towards utilizing public health facilities and personnel." 11

However, the miners placed the blame solely with the coalfield doctors. For miners, the Boone Report confirmed what they already believed about their communities: they were receiving substandard care at the hands of the coalfield medical system, and something needed to change. When the Fund was established in 1948, there was immense excitement among miners and in coalfield communities. They saw the Fund as a definitive way to "correct the evils of company doctors and hospitals," ensuring that miners and their families would finally have access to expert, unbiased care. ${ }^{12}$ The Fund contracted with doctors, paying them retainer fees in addition to fee-for-service billing to ensure there were doctors to care for the miners covered under the Fund. The doctors were still independent, and many of them were the same doctors that had received the ire of the miners in the past. However, under the auspices of the Fund the doctors were held to a high standard of care. The Fund was a true single-payer system, with records and billing all coming to the same central location. The Fund actively monitored patient outcomes and broke ties with individual physicians who had poorer-than-average outcomes or charged higher-than-average fees. As it grew in success, it also established its own independent hospitals and clinics. Miners and their families knew that if they went to the local hospital or

\footnotetext{
${ }^{11}$ Boone report, 90.

${ }^{12}$ UMWA Proceedings, 1946, 291.
} 
doctor's office and presented their benefit card they would receive medical care free of change. At the time of its establishment, there was no other program like it in the country. Miners saw it as an important reform in healthcare delivery in their communities, and they trusted the Fund physicians in a way they had not trusted the other coalfield doctors. The Fund directly addressed their concerns and actively intervened when necessary.

It is clear that miners tended to have a very dim view of their local physicians. How did their physicians feel about them? Unlike miners, physicians did not leave a record of numerous public debates about their relationships and attitudes towards their patients. While they did have their version of constitutional conventions, like those referenced above for the UMWA, these state and national medical association meetings did not tend to focus on physician-patient relationships. They instead focused on resolutions related to the business of medicine with occasional public health topics. For instance, of the thirty-two resolutions passed at their 1944 National Meeting, the AMA delegates only took up three that directly related to patient care. ${ }^{13}$ Individual physician members of the AMA were more concerned with the medical care of their mining patients. Reviewing the memoirs of coalfield physicians provides an important insight into their relationships with their patients. Of course, no physician is going to write a memoir in which he or she states that he or she disliked or did not trust miner patients. This caveat must be kept in mind when reviewing the memoirs. Even with this, coalfield physicians overwhelmingly looked back on their practices with fondness, although with varying degrees of paternalism towards their patients. One such memoir, Doctor Woman of the Cumberlands, by May Cravath Wharton, traces the career of a Progressive-Era female physician who moved to Cumberland County, Tennessee in 1917. Her memoir contains touching, compassionate stories

\footnotetext{
${ }^{13}$ Proceedings of the House of Delegates of the American Medical Association, 1944.
} 
of her interactions with her miner patients and their families. One such story relates her interaction with an elderly woman dying of liver cancer, and how she visited her remote cabin regularly to draw fluid off of her abdomen to keep her comfortable. ${ }^{14}$ However, at the same time she regularly discusses the ignorance of her patients, at one point describing her new community as a "Lost Colony."15

Another memoir detailing physician life in the coalfield is that written by Roland Sharp, DO. Dr. Sharp was a West Virginia physician who had a 75-year career including 17 years spent as a coal company doctor. He was the founding president of the West Virginia College of Osteopathic Medicine and a Pocahontas County native. After completing medical school, he moved to Mullens, West Virginia to begin work as a company doctor for the West Gulf Coal Company. The area was in dire need of physicians, and during his first week of work he delivered eight babies - a very large number for a family physician at the time. ${ }^{16}$ He enjoyed his work, describing his patients as "good” and reported “...they appreciated me. I don't know many hams I carried home, dozens of eggs, beef. They loaded you up with everything like that. That was in addition to the three dollars a month they paid you." ${ }^{17}$ His memoir discusses fond relationships with his patients and his dedication to trekking through deep winter snow to isolated homesteads to see sick patients and deliver babies.

Sharp is overwhelmingly positive toward the miners, and his writing lacks the paternalism and shock over coalfield conditions. Perhaps this was because Sharp, as a native West Virginian, did not experience the coalfields as a foreign and exotic place. Rural Pocahontas

\footnotetext{
${ }^{14}$ May Cravath Wharton, Doctor Woman of the Cumberlands, (Nashville: The Parthenon Press, 1972$), 83$.

15 Ibid, 17.

${ }^{16}$ Roland Sharp, Roland Sharp, Country Doctor: Memories of a Life Well Lived (Dunmoore: Pocahontas Communications Cooperative, 2008), 108.

${ }^{17}$ Ibid, 111.
} 
County at the time was not much different than the rural coalfield communities. Towards the end of his time in the coalfields, Sharp was directly contracted and employed by the UMWA, but he did not specify if this was as part of the Fund. ${ }^{18}$ However, like many physicians in the time period, he did have a dim view of the universal health insurance offered by the UMWA. He discussed miners and their families who "came in to see you [that] didn't have anything wrong with them. They just came in because they were paying the doctor." He believed they were wasting his time and valuable resources to seek unnecessary medical care, which gave him "a good idea of what socialized medicine would be like."19

Other coalfield physicians showed interest in working with the UMWA in its new healthcare delivery system. This is evidenced by articles published in the West Virginia Medical Journal (WVMJ). In January of 1950, the $W V M J$ publication committee addressed "whisperings to the effect that the United Mine Workers Welfare Fund has been wrecked by the inroads of the medical profession; that it will lead to state medicine, etc." It definitively stated that "as far as our observation of the Fund has gone, the profession is satisfied and the patients are likewise satisfied. Certainly it has ameliorated the lot of the miner medically and has pioneered in the field of labor-medical relationships." ${ }^{20}$ In April of that year it published an article by John Morrison, Area Medical Administrator for the Fund in Charleston, about the Fundamental underlying principles of the Fund. These centered around the belief that a community hospital and health services were the responsibility of a community in much the same way maintaining a fire department and police force were, and that Fund hospitals served vital community roles. ${ }^{21}$ In

\footnotetext{
${ }^{18}$ Ibid, 106.

${ }^{19}$ Ibid, 109.

20 WVMJ Publication committee, WVMJ 46, no. 1, 25-26.

21 John T. Morrison, "Principles Guiding the UMWA Welfare and Retirement Fund: Medical, Health and Hospital Section", WVMJ 46, no. 4, 97-101.
} 
1956, the journal covered the Conference on Medical Care in the Bituminous Coal Mine Area as well as the dedication ceremonies for several UMW hospitals. ${ }^{22,23}$

However, by 1957 this relationship had deteriorated due to the Fund's controversial decision to remove physicians from its approved list based on concerns about their medical competence. This was especially pronounced at the state and national levels of organized medicine. In August of that year, the WVSMA House of Delegates passed a resolution condemning the Fund, stating "there have been reported many instances of friction and criticism between the medical administration of the UMWA Health and Welfare Fund and the members and between the liaison committees of component medical societies." 24 The Fund also raised the ire of the West Virginia chapter of the Academy of General Practice for its insistence on using board-certified specialists in place of general practitioners. In 1955, the West Virginia delegation to the AMA Annual Conference introduced a resolution condemning the Fund for this, stating it "grievously questions the integrity and professional qualifications of the general physicians in West Virginia." 25 After several years of work by Dr. Draper with the AMA and organized medicine leaders around the country, the Fund and organized medicine reached an uneasy truce. In 1960 the $W V M J$ even published an article by Draper detailing the successes and importance of the program. ${ }^{26}$

This is not to say that organized medicine ever fully accepted the Fund or accepted medical activism by the organized labor movement. In the same 1960 issue in which Dr. Draper

22 "Medical Care in Coal Mine Areas Discussed at May Conference", WVMJ 52, no. 6, 188-189. This conference was sponsored by the AMA's committee on medical care for industrial workers but also heavily featured content by the Fund's local Area Medical Administrators.

23 "Dedicatory Ceremonies Planned for New UMW Hospitals", WVMJ 52, no. 5, 161.

${ }^{24}$ Copy of Resolution by West Virginia State Medical Association House of Delegates, Fund Archives, Series 3 Subject Files, Box 6, Folder 2.

${ }^{25}$ Copy of AMA House of Delegates Resolution, Fund Archives, Series 3 Subject Files, Box 6, Folder 2. 26 Warren F. Draper, “A Hospital Network for Coal Miners and Their Families”, WVMJ 56, no. 2, 70-73. 
had an article, the $W V M J$ reported that the AFL-CIO had engaged in an "all-out campaign in support of the Forand Bill. Leaders of the labor union repeatedly attacked the American Medical Association for opposing the bill., ${ }^{27}$ The bill in question aimed to expand medical care for Social Security beneficiaries, which the AMA believed was one step on the slippery slope to socialized medicine. In 1963, the state publication of the WVAGP published an article highlighting the financial woes of the Fund. It declared, with a certain degree of schadenfreude, that industry decline was "forcing a retrenchment in a pioneering experiment in hospital care that was being called 'a bright new hope' only a little more than six years ago." 28

The hostility between organized medicine and organized labor was especially pronounced at the national level. The recurring disagreements between organized medicine and organized labor centered around the Fund's insistence on policing healthcare quality in the coalfields and the AMA's belief that the Fund violated the principle of free choice of physician. The freedom to choose their own physicians had been a frequent and loud demand amongst coal miners, as mentioned previously. One of the biggest successes of the Fund was its effort to procure expert medical care for its beneficiaries. This meant that they limited the physician panel. For miners, this was not an impingement on their freedom of choice. The Fund was ensuring that they would have quality physicians dedicated to caring for miners, and for miners this was freedom of choice, via the Fund, and freedom from biased physicians. The AMA did not agree, and instead believed that the Fund's closed panel system was a direct infringement on patient rights to free choice of physician.

The Fund was very cognizant of this dispute over choice of physicians, in no small part thanks to the efforts of Dr. Draper to be an intermediary between organized medicine and 
organized labor. One such letter from the Fund archives focuses on giving advice to Draper about tailoring a 1959 AMA address to emphasize the Fund was not, in fact, impinging on free choice of physicians. ${ }^{29}$ The AMA strongly disagreed with this assertion, and throughout the 1950s they passed numerous resolutions and published numerous editorials and newspaper articles attacking the Fund and emphasizing the importance of unrestricted free choice of physicians. In 1957 the AMA House of Delegates passed a resolution stating that the Fund's impingement on free choice of physician was "tending to lower the quality and availability of medical and hospital care." 30 The Illinois delegates the following year went a step farther and resolved that any physician participating in plans such as the Fund was engaging in unethical behavior and should not be allowed in local medical societies. ${ }^{31}$ The AMA, in addition to taking their complaints to the public via newspaper articles, published a pamphlet called "The Fifth Freedom." It put free choice of physician on the same footing as the right to free speech and freedom of religion. ${ }^{32}$ It was not entirely bleak for the Fund, though. Some physicians in 1958 did stand up for the Fund, including a delegate from West Virginia who supported the Fund in its endeavors to rid the coalfields of incompetent doctors. They did not believe that this constituted the Fund infringing on patient rights but rather was an effort to clean the house of medicine of "chiseling doctors." ${ }^{33}$ As with other Fund issues, and, later, black lung disease, there was often room for a disconnect between the relationships of rank-and-file physicians and the upper levels of organized medicine.

\footnotetext{
${ }^{29}$ Letter from Dr. P.S. to Draper, April 7, 1959. Fund Archives, S3 Subject Files Box 11 Folder 12

${ }^{30}$ From Proceedings American Medical Association, December 1957. S3 Subject Files Box 6 Folder 1.

${ }^{31}$ AMA House of delegates resolution, 6/22/58. S3 SF Box 6 F1.

32 "The Fifth Freedom", S3 SF Box 6 F1.

${ }^{33}$ Report on 1958 AMA House of Delegates proceedings by Dr. Gordon Meade, S3 SF B5 F15.
} 
The Fund improved health outcomes significantly in the coalfields. Miners and their families had guaranteed access to high-quality healthcare. This not only meant that miners had unbiased representation in workplace injuries and diseases cases, but it also meant that their wives and children had access to good medicine. However, despite this, there was significant conflict with organized medicine, especially the upper levels of the AMA and WVSMA. These conflicts added to the longstanding distrust that many miners had for the medical community. $\mathrm{T}$ In the late 1960s, when coalfield physicians they deeply respected began telling them of a vast coverup of black lung disease by the medical establishment, it tracked with their past experiences with coalfield physicians and played a large role in shaping the narrative of black lung disease.

\section{British Physicians and their Miner Patients}

The relationship between British physicians and their Welsh coalfield patients paralleled that of the West Virginia coalfields in several ways. As in the US, there were significant concerns voiced by miners and their families with respect to both the impartiality of the physicians as well as their competency. Steven Thompson, for instance, discussed coalfield disputes between the medical community and its patients. ${ }^{34}$ As he points out, recurring themes of dispute were questions of the physicians' professional attitudes towards their patients, their competency, and their availability to their patients. For example, in 1915 a miner's wife encountered significant difficulty during her labor requiring the intervention of a physician. The miner had to visit three different physicians' offices and was turned away at each office before finding someone to assist his wife. Another instance of gross neglect was when a man suffered a

\footnotetext{
${ }^{34}$ Stephen Thompson, "Paying the Piper and calling the tune?: Complaints against doctors in workers' medical schemes in the South Wales coalfields" in Jonathan Reinarz \& Rebecca Wynter (eds), Complaints, Controversies and Grievances in Medicine : Historical and Social Science Perspectives (London: Taylor and Francis, 2019)
} 
crushing injury in the mine and died because of a dispute between the physicians in the community over who had medical authority over the patient. ${ }^{35}$ And, as in the American coalfields, there was a concern about the impartiality of employed coalfield physicians. Miners were concerned that their doctors would err on the side of pleasing their employers, at the expense of miner health. ${ }^{36}$ For their part, coalfield doctors could demonstrate the same kind of paternalism and seek the same kind of power differentials that existed in American coalfields. ${ }^{37}$ This eventually created conflict over the control of medical knowledge, with both miners and their physicians claiming true knowledge of miners' bodies and health.

However, the relationship between British medicine and British miners was different from the American experience in three very important ways. First, by the end of the $19^{\text {th }}$ century, mining communities, particularly in South Wales, had assumed control of their medical care under worker-driven medical aid societies. Second, the professionalization of medicine in Great Britain was intimately linked with the mining profession. Third, the mining industry, and miners' bodies, were nationally romanticized. This set British miners and British medicine down a very different path than the United States.

There was a significant amount of variability in working conditions and culture across the British coalfields. English and Scottish coalfields had different labor relations, different health issues, and different cultures than the South Wales coalfields. However, a commonality among the coalfields was that miners had access to medical care as a result of their employment. Initially, as in the United States, this was offered by the coal companies as a way to ensure a

\footnotetext{
35 Thompson, 98.

${ }^{36}$ David M. Turner and Daniel Blackie, Disability in the Industrial Revolution: Physical impairment in British coalmining, 1780-1880, (Manchester: Manchester University Press, 2018), 81.

${ }^{37}$ Kirsti Bohata, Alexandra Jones, Mike Mantin, and Steven Thompson. Disability in industrial Britain: a cultural and literary history of impairment in the coal industry, 1880-1948 (Manchester: Manchester University Press, 2020), 66.
} 
healthy populace and good public relations. As the labor movement strengthened, control of these medical schemes became a key protest point. In South Wales, the miners eventually obtained control of medical aid societies. These societies had a wide variety of functions, but one of their most important was providing comprehensive medical care (with the occasional exception of midwifery) to miners and their families. The most famous of these societies, the Tredegar Medical Aid Society, expanded its service such that by 1920 its beneficiaries had the services of five doctors, a surgeon, two pharmacists, a physical therapist, a dentist, and a visiting nurse. ${ }^{38}$ This society later provided a key inspiration to the founder of the National Health Service, Aneurin Bevan.

The societies were managed by a workmen's committee which was responsible for hiring physicians, mediating disputes between patients and physicians, and dismissing and censuring physicians. Organized medicine was outraged by this lay control of their profession, with BMA representatives accusing the committees of turning physicians into "wage slaves." There were also accusations that patients were forced to leave their established doctors for society-employed doctors to prove their loyalty to the union. ${ }^{39}$ These concerns were the same that would be later voiced by the AMA and state medical societies over the actions of the Fund. While the Fund was able to exercise a small degree of control with its physicians, the scope of the medical aid societies and their popular support meant that all of the British coalfield medical landscape was altered. Members of the societies were encouraged to attend doctor interviews and cast votes to determine which candidates would be hired, leading to unprecedented situations such as one

\footnotetext{
${ }^{38}$ Stephen Thompson, "A Proletarian Public Sphere: Working-Class Provision of Medical Services and Care in South Wales" in Anne Borsay editor, Medicine in Wales 1800-2000: Public service or private commodity? (Cardiff: University of Wales Press, 2003).

39 Thompson, Medicine in Wales, 94.
} 
physician interviewing for a job before 400 members of the local aid society. ${ }^{40}$ Members of the societies were also encouraged to attend public hearings in which complaints and grievances about the doctors were aired and discussed. In Britain, especially in South Wales, the miners obtained a truly free choice of physician with direct, rank-and-file involvement in policing its healthcare. This was the dream of the American miners demanding that they be allowed to choose their own company physicians. The result was that, despite lingering concerns and misgivings, British miners felt a great degree of control over their healthcare, resetting the patient-physician power differential.

Why did British organized medicine allow this to continue without the national and harmful attacks that would later characterize the AMA's fight against the Fund? One major component of this was the degree to which the British public romanticized the miner. Miners' lives and bodies were of great popular national interest, with periodicals frequently running human interest stories about mining life. Mining disasters were covered with salacious detail and intensity, and miners themselves were often believed to express unique physical characteristics that distinguished them as a race apart from their countrymen. ${ }^{41}$ This same degree of interest never developed in the American popular press and imagination. Miners, while still believed to be a race apart due to their poverty and isolated lifestyles, were never venerated or followed with that level of interest in America. For the most part, the idealization of the coal miner is a relatively new development in Appalachia, with Appalachian identity—especially in West Virginia - tied to notions of miners and the coal industry. This was not true in Britain. The health and wellbeing of miners, apart from their importance during wartime or as part of the industrial

\footnotetext{
40 Thompson, Medicine in Wales, 91.

${ }^{41}$ Bohata et al, 69.
} 
economy, were matters of national interest. To protest programs that directly benefitted these individuals, therefore, would damage the emerging reputation of the professional medical class.

The second reason why organized medicine related to miners in a unique way had to do with the development of the modern British medical system, including its professionalization, which was directly linked to industrial health, especially mining health and safety. The pioneering medical schools in Scotland, Edinburgh and Glasgow, were adjacent to the Scottish coalfields. This linked the development of medicine, especially that of pathology, pulmonology, and anatomy with miner's health issues. ${ }^{42}$ Miners constituted a large local populace with numerous disease processes to study, and so their bodies became tools of medical training and advancement. The elite of British medical science earned their reputations studying miners, and so it was that physicians could become publicly-recognized experts by caring for miners. There were also simple financial motivations for British physicians to care about miners: coal company owners provided steady employment for the new generation of physicians, many of whom started their careers in the coalfields. ${ }^{43}$ The profession of medicine, and the individual careers of physicians, were entangled with the lives of miners and mining communities.

Several British physicians took advantage of this situation, and of the public's fascination with miners and mining communities, to launch successful writing careers. The most famous, A.J. Cronin, published numerous novels drawing on his time as a coalfield physician. His most famous work, The Citadel, won several awards and was later made into a popular motion picture. It drew heavily on his own personal experiences in the early days of his career. Like many outsider narratives of coalfield culture, there is a great deal of otherness projected towards the coalfield patients and community. The sights, sounds, and dialects experienced are portrayed as

\footnotetext{
${ }^{42}$ Turner and Blackie, 61 .

${ }^{43}$ Ibid, 65.
} 
being exotic and separate from broader British society. However, the protagonist physician (Andrew Manson) at the center of the story still expresses a great deal of empathy for his patients and disgust with his colleagues who did not fulfill their duties to their patients and communities. He was also frequently disgusted by the official response to health concerns, such as when he first arrived in his Welsh mining community and encountered a typhoid outbreak. The local health officers were not concerned despite the severity of the cases, and eventually he worked with another physician to bomb the sewer that was the source of the outbreak. ${ }^{44}$

Later, the protagonist experiences firsthand the large volume of patients requiring certificates for workmen's compensation after experiencing disease and injury in the mines. ${ }^{45}$ However, when Manson denies a compensation certificate to a clearly malingering man, the miners retaliate by withdrawing themselves from his patient care roster and transferring to another physician employed by the medical aid society. The inclusion of this anecdote in the novel illustrates a common theme amongst coalfield literature: that of the doctor, justified or not, suspecting miners' motives and honesty and the miners exercising their power as members of the aid societies. This illuminates the power differentials in the coalfields and also highlights the complexities of feeling that British physicians had towards their patients.

\section{Conclusion}

There were fundamental differences in labor-medicine relationships in Appalachia and in South Wales. While miners had the same concerns in both countries, namely concerns over quality of care and control of their healthcare, they were able to address these concerns in drastically different ways. In Wales, the miners gained control over their physicians and their

\footnotetext{
${ }^{44}$ A. J. Cronin, The Citadel, RosettaBooks: 2015, Kindle, 27.

${ }^{45}$ Cronin, 108.
} 
healthcare by the establishment of medical aid societies. American miners relied upon the UMWA and the foundation of the Fund to enjoy the same sense of control and confidence in their healthcare. This created two very distinct power structures. In Britain, the miners exercised significant lay control over the medical profession. This would later enable them to exercise control over medical knowledge, specifically the research and recognition of black lung disease. In the United States, miners never achieved this degree of power. They were able to exercise power through the UMWA and by extension through the Fund, but they never achieved the goal of individually choosing their physicians and dictating their care. They welcomed the Fund and believed that it satisfied their calls for free choice of physician and impartial medical care. However, at the end they were dependent upon the UMWA, the Fund, their ability to convince coalfield physicians to cooperate with them. American miners also never obtained any degree of control of medical knowledge, which would hamper their efforts towards black lung recognition. Organized medicine in America also never developed the connection to industry and mining that characterized organized medicine in Britain in the $19^{\text {th }}$ and $20^{\text {th }}$ centuries. Modern medicine and the professionalization of the field was occurring in Britain contemporaneously with the industrial revolution and the explosion of the mining industry. This, combined with the popular fascination with British miners, meant that the development of medicine was linked with miners. This created a much longer and closer working relationship that allowed for a smooth transition into the National Health Service and a much earlier recognition of black lung disease by British medicine. By the time the coal industry took off in America, however, the professionalization of American medicine was well underway. It had succeeded without tying itself to industry or miners, and industrial medicine proceeded as an afterthought for the American medical profession. There were also not large numbers of young physicians flocking 
into the American coalfields, and this crucial exposure of doctors to coalfield culture and health never happened. Coalfield medicine was never glamorized and no motion pictures were made about its practitioners. While coalfield physicians appeared to care about their patients and their diseases, the larger body of medicine did not have the same concern. In fact, it was more concerned about perceived attacks by labor on its autonomy than it was about health crises facing coalfield patients.

American medicine had a frequently-adversarial relationship with organized labor, especially the UMWA. American miners distrusted their physicians, and their physicians maintained strong paternalistic attitudes and practices that enabled them to maintain the control of medical knowledge. Thus, when miners began demanding action on black lung disease, they could not claim power over knowledge and had no long-term working relationship with medicine to remove this barrier. In Britain, however, miners were able to exercise control over their physicians with the overall cooperation of organized medicine. This allowed organized medicine to claim expertise during its professional development while also presenting a public image of concern for a popular demographic. These relationships directly contributed to the battle for black lung recognition, the topic of the next chapter. 


\section{Chapter Two: The British struggle for recognition}

The black lung struggle in Great Britain is more than simply one of a reticent industry and medical profession recognizing a deadly disease. It is also illustrative of multiple changes occurring in British society contemporaneously with the fight. The increasing concern for the wellbeing of the working class, as evidenced by the attention paid to black lung, reflected a shift in British politics. Conservative cohorts lost power as the Labour Party gained traction. The Labour Party was dedicated to social and economic reform, with a goal to create a more equal society for all British citizens. This idea of equality involved not just economic equality, but health equality as well. This meant providing healthcare to all citizens, equal in quality, regardless of ability to pay. Important relationships were formed between medicine, labor, and the Labour party during the fight for black lung recognition which were fundamentally different than the same relationships between medicine and labor in West Virginia.

The fight for recognition of black lung had its roots in the interwar and World War II period, and it was occurring in the context of other important social and economic changes and struggles in Great Britain. Like other such extractive industries, and like other international coal industries, the British coal industry was victim to boom-and-bust cycles. Periods of immense production and employment would shift to widespread poverty and idled collieries, as domestic and international markets together caused the price of coal to plummet. Coal also played a large role in war preparedness, and the efficiency and management of the industry was of great concern to the British government. In World War I, concern was so great that the government took control of the industry in order to ensure vital supplies for the war effort. ${ }^{1}$ It also created the

\footnotetext{
${ }^{1}$ Chris Williams. Capitalism, Community, and Conflict: The South Wales Coalfield, 1898-1947. (Cardiff: University of Wales Press, 1998), 20.
} 
Health of Munition Worker's Committee, which focused on improving health as a way to increase production. $^{2}$

The government continued to invest in miners' health, even when it was not directly connected to national defense. Following the War, it established the Industrial Health Research Board in 1928. Later it established the Industrial Pulmonary Diseases Committee (IPDC). ${ }^{3}$ However, while the government showed interest in the health of miners, the industry was economically threatened. Initially after the war there was a boom as demand for coal skyrocketed, leading to a huge increase in employment, jobs, and the price of coal. This demand quickly fell. By 1920, the coal industry was headed into yet another bust cycle. The government, now dealing with a faltering industry and striking miners, soon returned control of the industry back to private hands. ${ }^{4}$ There was a brief uptick in 1922, as exports to America increased in the aftermath of mine conflicts there. As these conflicts ended and American production again increased, hard times returned to the British collieries. ${ }^{5}$ The global depression only exacerbated the situation, and the interwar years in the coal fields were times of woe and want. Unemployment and low wages were thus a significant concern for miners and their unions.

World War II somewhat reversed this decline. Welsh coal exports were high in the early years of the war. After France fell, however, a major export market was lost. French demand was satisfied by German coal as the Nazis took over an ever-larger portion of Western Europe. ${ }^{6}$ It seemed that bust times would return, but as the war effort grew and the Allied Forces enjoyed greater success, the demand for coal soared. As Britain transitioned from war to peace, the coal

\footnotetext{
${ }^{2}$ McIvor and Johnston, 82 .

${ }^{3}$ Ibid.

${ }^{4}$ Ibid, 20.

${ }^{5}$ Ibid, 23.

${ }^{6}$ Williams, 24.
} 
industry remained of great concern to the government. International coal reserves were critically low, and the government was eager to discharge miners-turned-soldiers as quickly as possible in order to ramp up production to rebuild Europe. ${ }^{7}$ A new Labour government in 1945 nationalized the coal industry, which enabled sweeping health and safety reforms in the industry that built upon the advances achieved during the black lung fight.

It was in this background of war and peace, and boom and bust, that the black lung struggle occurred. Organized labor led the fight, specifically the South Wales Miners' Federation (SWMF) and the Miners' Federation of Great Britain (MFGB) ${ }^{8}$ The SWMF, as indicated by its name, was the leading union in the Welsh coalfields. In the aftermath of World War I, as the industry began to descend into the severe interwar bust period, the SWMF was an active force in the coal fields. It blasted the colliery owners for failing to apply an appropriate portion of their substantial wartime profits to the aid of unemployed and underemployed miners. ${ }^{9}$ Elsewhere in the country, the MFGB spent much of its energy in the interwar years demanding that the government and the coal industry take a role in shoring up wages as well as expressing concern about the sagging export market. The topics of wage agreements and exports comprised nearly the entirety of the presidential addresses at national conferences during the interwar years, and are thus indicative of the main priorities of the union, at the MFGB's annual national meetings in the interwar years. ${ }^{10}$ While yearly reports of the most tragic accidents were mentioned, such as the Gresford Colliery explosion that killed 265 miners in November of 1934, the overall health

\footnotetext{
${ }^{7}$ Memorandum by the Minister of Labour and National Service. April 17, 1945. CAB 66/65/7. War Cabinet files, National Archives of the United Kingdom.

${ }^{8}$ The SWMF merged with the MFGB to form the National Union of Mineworkers in 1945.

${ }^{9}$ Chris Williams. Democratic Rhondda: Politics and Society, 1885-1951. (Cardiff: University of Wales Press, 1996), 130.

${ }^{10}$ Speeches 1921-1930; Speeches 1931-1940. National Union of Mineworkers online archives (hereafter NUM online archives). http://num.org.uk/archives/
} 
and safety of the miners took an official backseat at large gatherings to the very pressing concerns of wages and the overall economic health of the industry. ${ }^{11}$

However, despite the severe economic hardships faced by their members, the SWMF and the MFGB still devoted time and attention to occupational health in this time period. The SWMF was especially concerned, as South Wales appeared to have a substantially greater proportion of occupational lung disease compared to other coal regions. ${ }^{12}$ The SWMF recognized early on that there was a dust disease related distinctly to coal dust inhalation, for miners were developing significant respiratory diseases despite a low exposure to silica dust, which was believed at the time to be the only dangerous dust in the mines. The SWMF employed its own experts who conducted research and examined miners in order to build the case that there was a significant, previously unrecognized disease afflicting Welsh miners. ${ }^{13}$ Initially, these efforts took the form of proving that men were being diagnosed with silicosis despite working pits with silica levels below the thresholds set out by compensation laws. Clearly, in the minds of the SWMF, there were men with severe dust disease who had not apparently been exposed to significant amounts of silica. These early efforts were also used as an argument against the thresholds set out by the laws, which at one point required miners to work in rock with an $80 \%$ silica composition to receive compensation for their disease. ${ }^{14}$ By the 1930 s, miners wishing to receive compensation for silicosis had to prove they worked on rocks with a $50 \%$ or higher silica composition, and in South Wales 130 out of 300 men diagnosed with silicosis were unable to receive compensation because of this threshold. ${ }^{15}$ The SWMF commissioned independent epidemiological reports

\footnotetext{
${ }^{11}$ Joseph Jones, President MFGB, Presidents Address. July 15, 1935. NUM online archives.

${ }^{12}$ McIvor and Johnston, 188.

${ }^{13} \mathrm{Ibid}, 188$.

${ }^{14}$ Ibid, 190.

${ }^{15} \mathrm{Ibid}, 191$.
} 
investigating dust disease in the Welsh coalfields. A. Hubert Cox released a report for the SWMF linking carbon content concentrations to disease. ${ }^{16}$ J.H. Davies released an additional commissioned report in which he also outlined and called for measures to suppress dust exposures for miners. ${ }^{17}$

The SWMF's efforts were successful. Soon, the press was taking notice of the situation and in 1937 the government began a Pneumoconiosis Investigation to further examine the issue. This investigation, which ended in 1942, directly led to the recognition of black lung and the change in compensation laws. The advocacy of the SWMF did not end with this official action, however. One of the most crucial decisions in this investigation was to investigate not just miners, but the coal trimmers who shoveled coal into ships for export out of Great Britain. By taking the problem out of the mines, the silica issue was completely bypassed. It was a union compensation secretary, Harry Finch, who suggested this arm of the study, and thus provided crucial evidence that coal dust could and would cause disabling lung disease in those exposed to it, irrespective of co-exposure to silica. ${ }^{18}$ In addition to advocating for recognition of the disease and expanding compensation laws to include it, the SWMF also advocated for dust control measures. ${ }^{19}$

While the SWMF was leading the charge on black lung, the MFGB was also active during this time period. In 1936, Joseph Jones remarked in his annual President's Address that "the question of silicosis and other industrial diseases have also been dealt with us during the year" and promised to "spare no possible effort" to ensure that all men would receive appropriate

\footnotetext{
${ }^{16}$ Ibid, 192.

${ }^{17} \mathrm{Ibid}, 193$.

${ }^{18} \mathrm{Ibid}, 194$.

${ }^{19} \mathrm{Ibid}, 195$.
} 
compensation. ${ }^{20}$ In 1942, in an address exhorting his union members to rise to the duty that the war demanded of them, President William Lawther condemned the government for failing to believe miners and act quickly on their concerns about dust disease, and called them to "answer the cry of the injured...by immediate redress. ${ }^{21}$ The MFGB provided assistance to the SWMF, supporting their calls for investigation into dust diseases in the Welsh coalfields, as well as arguing their case before the Home Office. ${ }^{22}$ The MFGB had dedicated compensation committees, and raised concerns with falling safety standards, especially dust levels, as wartime production intensified. ${ }^{23}$ The work of the MFGB and SWMF were the main actions that led to the 1943 amendment of the Workman's Compensation schemes that allowed coverage for black lung.

The work of the unions did not end after 1943, however. Once black lung was officially recognized, work remained, especially in developing an effective preventive strategy. Coal dust was now acknowledged as a dangerous occupational pathogen, and the unions pushed for a reduction in coal dust in the mines. The MFGB/NUM's Safety and Health Sub-Committee spent considerable time pushing for the company owners to implement dust control measures, and to set dust particle size and concentration limits that would most protect the lungs of miners. ${ }^{24}$ The founding charter of the NUM even prioritized dust suppression as one of its founding operational clauses. ${ }^{25}$ However, significant debate continued about exactly what constituted safe levels of dust in the mines. Was it best to regulate and monitor dust on the basis of concentration alone, or was the size of the coal dust particles themselves important? In order to answer this, the

\footnotetext{
${ }^{20}$ John Jones, President MFGB, President's Address. July 20, 1936. NUM online archives.

${ }^{21}$ William Lawther, President MFGB, President's Address. July 20, 1942. NUM online archives.

${ }^{22}$ McIvor and Johnston, 190.

${ }^{23} \mathrm{Ibid}, 196$.

${ }^{24} \mathrm{Ibid}, 198$.

${ }^{25} \mathrm{Ibid}, 200$.
} 
government commissioned a large-scale study to methodically and scientifically, using the latest principles in epidemiology, examine the exact correlation between dust concentration, particle size, and the severity of black lung. The NUM formed a critical role in steering this research project which endured for the next 20 years and provided long-term data about the development, exposure, and prognosis of black lung. ${ }^{26}$ Finally, the NUM also worked on the international level, with the Miners' International Union, to share research on dust disease across international lines and to assist miners in other countries to pursue the gains that the NUM had accomplished in Great Britain. ${ }^{27}$

The unions played a large role in black lung recognition, but they were not alone. Organized medicine also contributed to the process, although not as much as had organized labor. Organized medicine became most active in the issue after recognition was achieved in 1943 and pushed for greater recognition of the condition as well as dust containment issues. Amongst these contributors was the Association of Industrial Medical Officers (AIMO), an organization dedicated to improving and studying the health and unique conditions affecting industrial workers. This was a necessary organization, for many local public health officials had no interest in occupational diseases affecting workers living in their districts, black lung included. ${ }^{28}$ In fact, one of its earliest meetings focused on the importance of collaboration between public health services and industrial hygiene. ${ }^{29}$ Founded in 1935, it brought together physicians engaged in the treatment of employees in all branches of industry in the UK at the time. Its scope was necessarily broad, for not only was it concerned with the health of miners,

\footnotetext{
${ }^{26}$ Ibid 118.

${ }^{27}$ William Lawther, President NUM, President's Address. July 6, 1953. NUM online archives.

${ }^{28}$ McIvor and Johnston, 192.

29 “Medical Diary," The Lancet 230, no.5963 (1937): 1410.
} 
but also the health of factory workers, shipyard employees, and every other industrial worker spread across all of British industry at the time.

Despite this broad range of interests and responsibilities, AIMO dedicated time to the question of lung diseases in coal miners and was one of the earliest official bodies to do so. By 1938, it was already discussing the importance of radiology in pneumoconiosis diagnosis. At its quarterly meeting on January 28 of that year, the Medical Inspector of Mines, Medical Inspector of Factories, Mines Department representatives, and members of the Silicosis Board all spoke on issues affecting the coal miner. However, at that point in time the discussion centered on silicosis, highlighting the toll it was taking on miners in the South Wales coalfields. Crucially, the members of the Silicosis Board, Drs. C.L. Sutherland and Dr. A. Meiklejohn, specifically stated that, with respect to the potential for another lung disease to exist in miners, "silicates may set up changes in the lung suggestive of some form of pneumoconiosis. It was likely that these changes were not producing an incapacitating disease." ${ }^{30}$ This certainly added to the confusion around the topic and contributed further to the perception in the medical community that silicosis was the only significant dust disease affecting the British miner. Another, though nonoccupational lung illness, which also plagued coal mining communities at the time was tuberculosis. As late as 1940, Dr. Sutherland was reporting to the Association that newlydiscovered radiological and pathological findings, which he described as "cricket-ball masses" and nonspecific cavitary lesions, were almost certainly due to unrecognized tuberculosis, directly rejecting the theory that an unidentified dust was causing these findings. ${ }^{31}$ These findings were later described and classified among those consistent with the most severe black lung cases.

\footnotetext{
30 “Association of Industrial Medical Officers," The Lancet 231, no. 5972 (1938): 380.

${ }^{31}$ Charles L. Sutherland. "Tuberculosis in the Silica-Risk Industries”, The Lancet 235, no. 6089 (1940): 893-896.
} 
Although AIMO was somewhat slow to recognize black lung as a disease separate from silicosis, the situation began to change after the 1943 recognition. The next year, AIMO founded the British Journal of Industrial Medicine, which quickly became a world leader in the dissemination of industrial medical knowledge. By the third issue, the subject of black lung was being discussed in the pages of the journal, with papers highlighting the research that had been accomplished to bring awareness to the disease (although they placed the credit entirely at the feet of the medical profession, and overlooked the contributions of the unions entirely). ${ }^{32}$ However, while the articles taking center-stage within the pages of the journal readily accepted the existence of the disease, regional chapters of the AIMO reported presentations at meetings that continued to question its existence. At the November 1944 meeting of the Nottingham chapter, a Dr. A. I. G. McLaughlin gave a talk on pneumoconiosis and reported that "Silicosis and asbestosis are probably the only true pneumokonioses, because the dusts of free silica and asbestos both produce fibrosis of the lung. As far as is known, other dusts do not produce fibrosis," which directly contradicted the findings reported by the BJIM in previous issues. ${ }^{33}$ Despite this, by the 1950 s the BJIM would become the world's chief medical journal regarding the black lung literature, and dozens of articles would be published over the next twenty years regarding the pathology, diagnosis, management, and prevention of black lung.

The main body of organized medicine, made up of such organizations as the British Medical Association (BMA) and the Royal College of Physicians, was generally less involved with the dust disease issue. However, both of these organizations represented the entirety of British medicine, from pediatrics to geriatrics, obstetrics to tuberculosis. It would be impossible

\footnotetext{
${ }^{32}$ S.W. Fisher, "Health Hazards of Coal Mining", The British Journal of Industrial Medicine (hereafter BJIM) 1, no 3 (1944): 153-158. R.S.F. Schilling, "Industrial Health Research: The Work of the Industrial Health Research Board, 1918-1944.” BJIM. 1, no. 3: Pages 145-152.

33 "Proceedings of the Association of Industrial Medical Officers", BJIM 2, no 2 (1945): 122-124.
} 
to devote significant time to a very specific occupational disease at a time when severe communicable diseases, malnutrition, maternal mortality, and other major public health diseases affecting huge portions of the population were necessitating intervention. Despite this, the British Medical Journal (BMJ) regularly published scientific papers on the topic of coal miners' occupational lung diseases as well as publicized meetings of the AIMO. In many instances, the $B M J$ did not shy away from the controversy, frequently remarking on debates surrounding the topic. In 1932 at the annual national meeting of the BMA, an entire day was devoted in the Section of Pathology to the topic of occupational dust diseases, with a heavy emphasis on silicosis. Special attention was paid to the question of exactly what role non-silica dusts had in the development of miners' lung disease, and the president of the section stated that while "other silicates and the non-silicaceous dusts were held to be innocuous" he found "it difficult to believe that the ounces if not pounds of foreign material which may be found in the lungs at postmortem had had a negligible effect." 34

In 1934, the $B M J$ covered a debate held at a silicosis conference between two physicians studying the topic. The lack of silicosis exposure in South Wales coalminers experiencing a severe lung disease was debated, with one physician postulating that another dust possibly caused the disease, but others "warmly contested" this theory. ${ }^{35}$ In $1935, B M J$ published a comprehensive review article on silicosis and what was termed silico-anthracosis. Frustratingly, despite the author acknowledging that coal dust was a potentially damaging agent, he still stated that the lung disease affecting miners did not originate in coal dust, but instead in the likely exposure to silica that must always be present due to actions not directly related to drilling coal

\footnotetext{
34 "Centenary Meeting on the British Medical Association Held in London July 1932", British Medical Journal (hereafter BMJ) 2, no. 3735, 251-271.

35 "Silicosis: Rival Theories.", BJIM 1, no. 3817: 384.
} 
seams such as repairing roofs. ${ }^{36}$ Significant studies carried out by the unions had consistently failed to demonstrate appreciable silica presence in many mines.

In the years after recognition, the BMA was heavily concerned with the remaking of the nation's healthcare system after the War. The founding of the NHS was a contentious subject, and by no means a foregone conclusion, and it did occupy a significant percentage of the BMA's attention from 1943 to 1948 . However, the BMA did support the AIMO, and even assisted AIMO in establishing the BJIM. Furthermore, despite the existence of a journal specifically dedicated to occupational health after 1944, the $B M J$ continued to publish articles about black lung. This allowed dissemination of knowledge on the topic to an audience that otherwise may never have a reason or opportunity to learn about the condition, and it is significant that the $B M J$ gave it such precious journal space. It certainly reflects the importance of miner health to the British medical establishment, as well as to the nation as a whole. The $B M J$ also did not shy from publicizing the medical profession's own role in the failure to recognize and mitigate the dangerous effects of dust earlier. In 1947 at the meeting of the Section of Medicine of the Royal Society of Medicine, the $B M J$ recorded that the sudden explosion in diagnosed cases of black lung had been due to "the ignorance of medical men, who had assumed the condition to be bronchitis." 37

Thus, the main body of organized medicine appears to have enthusiastically embraced the topic after 1943, and the $B M J$, like the $B J I M$, published numerous articles and commentaries on the topics in the years that followed recognition. By 1950, the acceptance of black lung among mainstream British medicine was so complete that, in an article tracing the history of public

\footnotetext{
${ }^{36}$ S. Lyle Cummins. "Pneumoconiosis: With Special Reference to the Silico-Anthracosis of Coal Miners", BMJ 2, no. 3893:287-90.

37 “Reports of Societies.”, BMJ 1, no. 4512: 940-942.
} 
health advances in the country, the $B M J$ gave credit to organized British medicine for the recognition of black lung. In the article, which stated in its introduction that "For the most part, therefore, legislation in public health is a legal ratification of medical advance and not an initiation," the author (the former Chief Medical Officer in the Ministry of Health) listed the recognition of black lung amongst other "triumphs of industrial medicine" such as the prevention of TNT poisoning in factories during World War I. ${ }^{38}$

Another important party in the recognition of black lung was the Labour Party. The rise of Labour played a key role in improving the lives of miners in Great Britain. The Labour Party initially experienced its greatest stronghold in Wales, but throughout the interwar and World War II era it gained increasing amounts of power in local and national government. The support of the SWMF greatly contributed to its dominance in the region, and the Party's commitment to economic and social justice won support throughout the country. Labour MPs were overwhelmingly Welsh and largely miners and very intimately acquainted with the problems facing the British working class. ${ }^{39}$ Like the MFGB, the Labour Party was initially largely concerned with economic issues in the interwar years and it was this dedication to economic justice that largely contributed to their popularity in the country. The Labour Party experienced increasing power from the interwar period, through World War II, and into the postwar period. Its increasing presence in the government allowed the trade unions to air their concerns to a newly-sympathetic government, and Labour officials made sure to listen. In addition to the numerous economic changes made contemporaneously with the black lung battle, Labour officials also directed the formation of the key committees such as the IPDC and investigations

\footnotetext{
${ }^{38}$ Arthur S. MacNalty, "Fifty Years of Public Health Legislation”, BMJ 1, no. 4644: 48-53.

${ }^{39}$ Morgan, 173.
} 
that led to its recognition. ${ }^{40}$ Aneurin Bevan, the Minister of Health who spearheaded the formation of the NHS, was the son of a Welsh coal miner. His experience with coalfield medicine and the hardships of working-class life influenced his desire to see a truly universal health system that would provide high-quality healthcare to all, free at the point of service.

The Labour Party of the wartime and postwar period was also directly responsible for what was the most significant change ever to face the British coal industry: nationalization. The government had exercised varying degrees of control over the industry since World War I and the topic of nationalization of the coal industry was one that was dear to the unions and the Labour party. Labour accurately predicted the postwar coal shortage. Private ownership did not seem equipped to handle the demands of rebuilding Europe. Additionally, private ownership, and the capitalist economics that went with it, would forever doom the livelihood of the miners and the coal mining towns to boom and bust cycles. Private ownership had certainly not resulted in safe mines, nor had private owners willingly compensated their workers fairly for their injuries and occupational diseases. The shocking health statistics coming out of the coalfields thanks to the new epidemiological studies spurred on by the black lung issue made nationalization not just an economic priority, but a very real public health issue. ${ }^{41}$ Now that the Labour party, with a strong desire to enact socialist change throughout the country, had taken sweeping control of the government, the time had come to end private ownership of the coal industry.

The British coal industry was formally nationalized on January 1, 1947, under the control of the National Coal Board (NCB). The NCB quickly moved to rationalize the industry, closing underproductive collieries and introducing increasing levels of mechanization. ${ }^{42}$ The NCB also

\footnotetext{
${ }^{40}$ McIvor and Johnston, 83.

${ }^{41}$ Morgan, 177.

${ }^{42}$ Williams, Capitalism, Community, and Conflict, 25.
} 
prioritized the health of miners, appointing a Chief Medical Officer who oversaw a Mines Medical Service that focused on the health and safety of miners; it delivered a health service more comprehensive than even that of the fledgling NHS. ${ }^{43}$ It supplied a comprehensive consultation program as well as laboratories in each mining region for epidemiological research. ${ }^{44}$ The nationalization of the industry made it far easier than ever before to implement widespread prevention programs, both for accidents/disasters as well as for chronic occupational diseases such as black lung and the health programs of the NCB became models of industrial health. However, in the long term the ability of the NCB to juggle the demands of production with the demands of miners' health would be challenged, especially with increased mechanization which increased dust levels in the mines. The NCB would even face a lawsuit for its alleged failure to protect its miners from dust and the ravages of black lung. ${ }^{45}$ In general, however, the NCB provided greater safety to its members than had been afforded them under private ownership.

Black lung recognition was never assured, and in many ways it is remarkable that it happened at all. The interwar period was a very rough era for the country, and the challenges facing all of the parties responsible for black lung recognition were immense. The unions were struggling to not only achieve and protect such gains as paid holidays and minimum wage, but also struggling with declining enrollment as the industry suffered in the economic drought of the period. Organized medicine was facing epidemic levels of tuberculosis, high maternal mortality rates, childhood malnutrition, and numerous other serious public health crises. The Labour Party was dealing with all of these issues as well as attempting to wrest control of the government

\footnotetext{
${ }^{43}$ McIvor and Johnston, 107.

${ }^{44}$ Ibid, 111.

${ }^{45}$ Ibid, 128.
} 
from Conservative and Liberal politicians. These groups could conceivably have ignored the topic. The SWMF and the MFGB could have focused all of their attention on wages. Medicine could have lost itself to the debate over a state health service as well as so many other serious health concerns. The Labour Party could have prioritized economic change above all social reform, and its emphasis on social reform went beyond that of other European countries at the time. These groups all came together to recognize that a deadly disease was affecting British miners, and they all worked to mitigate its impacts once its existence was finally known. The unions appear to deserve the bulk of the credit for this victory, but without the cooperation and support of the other parties involved they would have been unable to secure such far-reaching gains in dealing with black lung. 


\section{Chapter Three: West Virginia Physicians and Black lung Recognition}

West Virginia coal miners started a mass wildcat strike on February 18, 1969. By March $1,30,000$ of the state's miners had walked out. ${ }^{1}$ For months, largely due to the efforts of three activist West Virginia physicians, the miners had developed an increasing awareness and concern over the respiratory condition known as "black lung disease." This strike was the culmination of months of unrest and activism, held in an effort to both acknowledge the disease and win compensation benefits for those disabled by the disease.

Alan Derickson lays the blame for the failure to recognize black lung at the feet of the company owners, organized medicine, and the failing UMWA. He asserts that the medical community viewed physicians contracted with the UMWA Welfare and Retirement Fund (Fund) as "dangerous renegades," and credited Dr. Lorin Kerr of the Fund for nearly singlehandedly driving US interest in black lung. ${ }^{2}$ These assertions do touch on an underlying friction between the mainstream medical establishment and the Fund, but they also discredit the efforts of many local physicians in coal mining communities to learn more about black lung.

In addition to Kerr, the physicians who have taken the spotlight in the history of black lung were its most vocal activists - the members of the Physicians for Miners' Health and Safety. This three-person committee consisted of Dr. Isidore Buff, a cardiologist; Dr. Donald Rasmussen, a pulmonologist; and Dr. Hawey Wells, a pathologist. It was their widespread efforts at education amongst the mining communities and their willingness to use the press in dramatic ways that ignited the BLA. The voices of other doctors, both as individuals and as members of state and local medical societies and professional organizations, have not been explored to nearly

\footnotetext{
1 Jerry Bruce Thomas, Appalachian Reawakening: West Virginia and the Perils of the New Machine Age, $1945-$ 1972. (Morgantown: West Virginia University Press, 2010), 268.

2 Derickson, 132.
} 
the same extent. Derickson mentions these voices but asserts that they were against recognition of black lung and against expanding compensation laws. There were surely physicians in coal mining areas who did not accept black lung as a disease process and were opposed to compensation for this disease, and many of these physicians had at least some tie to the coal industry.

Yet when one re-examines the records and writings of the physicians practicing in the Appalachian coal fields, a different picture emerges. Many more physicians were willing to acknowledge black lung than have previously been acknowledged, and their eagerness began shortly after the 1943 passage of British black lung compensation laws. They were interested in learning more about the disease and often took their own initiative in diagnosis and education. The medical establishment, led by state and county medical associations, also took steps to bring awareness to the disease process. Additionally, the medical community was quick to begin educational efforts after passage of black lung legislation in order to help its members identify the disease and assist miners in receiving compensation for it. The narrative that the medical community was largely against the "dangerous renegades" involved in black lung activism was established early by both the BLA and the mainstream media and has been accepted as fact by subsequent historians and journalists. This is an incomplete reading of these events and these physicians. The physicians in these coal mining communities, in the decades leading up to and during the black lung fight of 1968-1970, demonstrated much more willingness to learn about and diagnose the illness than they have received credit for.

Kerr and the medical directors and administrators of the Fund took a proactive role in disseminating new British medical research to Fund physicians. In the mid-1950s they began to invite international black lung experts to the American coal fields to examine their patient 
records and discuss the disease with American physicians. Among these visits were British specialists in 1952,1955 , and $1957 .{ }^{3}$ During this time period, Dr. Kerr also regularly reproduced and mailed black lung articles, usually in response to requests by coal country physicians wanting more information about the process. ${ }^{4}$ Dr. Leslie Falk, then an area medical administrator for the Fund in Pittsburgh, had even compiled a bibliography which was sent regularly to physicians who were interested in black lung research. This early bibliography included Public Health Service literature as well as proceedings from domestic black lung symposiums and publications in the West Virginia Medical Journal. ${ }^{5}$

Members of the Fund administration also organized internal conferences on the topic. One such conference was held in January 1957 regarding the disease and the need for further studies. ${ }^{6}$ In February there was a meeting of the "Pneumoconiosis Study Unit" in Pittsburgh. Later that year, in June, the administrators attended a meeting at Massachusetts General Hospital on the disease in which they reviewed numerous case studies, including pathology and radiology, of several miners in effort to determine if they were afflicted with black lung or other disease processes. A summary of the conference proceedings was sent to all UMWA administrators. ${ }^{8}$ In February 1958 these same administrators held yet another internal conference, led by Dr. Jethro

3 United Mine Workers of America Health And Retirement Funds Archives (Fund Archives), series III, Subseries Health Care Delivery; Box 13, Folder: Dr. Charles M. Fletcher's Visit 9-11/57; Box 13, Folder: Dr. Gilson's visit to US

4 Fund archives, series III, Health Care Delivery; Box 12, Folder: Pneumoconiosis General. 5 Letter from Dr. Falk to Dr. Thompson Ferrier, Russelton Area Medical Administrator for Fund, 1/6/54. Fund archives, series III, Health Care Delivery; Box 12, Folder: Pneumoconiosis Consultants. This same bibliography was regularly reproduced and sent to numerous other physicians around the country by multiple different administrators and officers within the Fund.

6 Letter to Dr. Warren Draper from Dr. Falk, 3/5/57. Fund archives, Series III, Health Care Delivery; Box 11, Folder: Pneumoconiosis Conferences. Dr. Warren Draper was the Fund's executive medical officer at the time. 7 Letter to Draper from Falk, 3/2/57. Fund archives, Series III, Health Care Delivery; Box 11, Folder: Pneumoconiosis Conferences.

8 Inter-office correspondence 7/19/57 on conference held 6/27/57. Fund archives, Series III, Health Care Delivery; Box 11, Folder: Pneumoconiosis Conferences. 
Gough (at that time the world's leading pathologist on the topic) discussing the variety of complications and presentations of the disease. ${ }^{9}$

These efforts proved crucial in educating American physicians about the disease process, but their success depended entirely on the willingness of the medical community in coal mining areas to hear these speakers and read these works. The community was willing. International experts were not met with suspicion or indifference but rather with acceptance and a readiness to learn more. Many local physicians and their medical societies were interested in holding their own conferences on the topic. In 1952, a Symposium on Coal Workers' Pneumoconiosis was held at the Golden Clinic in Elkins, WV. More than 100 physicians registered for the conference, with Fund administrators stating that the meeting "firmly established the possibility that there was a disease entity which might be called pneumoconiosis of soft coal miners which was causing disability among miners." ${ }^{10}$ In 1953, the Knoxville Chest Group (which had been formed with the encouragement of the local Fund officer) held a conference on the disease in Tennessee. ${ }^{11}$ In October 1955, another well-attended Symposium was held at the Golden Clinic, with opening remarks given by the president of the Barbour-Randolph-Tucker medical society. ${ }^{12}$ By 1957, other organizations had emerged with an emphasis on the topic, such as the "KentuckyVirginia Pneumoconiosis Society." The organization invited Dr. Kerr to their meeting in February $1957 .{ }^{13}$ Doctors at Harlan Memorial Hospital in Kentucky requested Fund officer presence at a proposed symposium on the disease in 1958, stating "We all have an obligation to

\footnotetext{
9 Office session report, 2/10/58, on session about Coal Workers' Pneumoconiosis held by Dr. Gough. Fund archives, series III, Health Care Delivery; Box 11, Folder: Pneumoconiosis Conferences.

10 Fund archives, Series III, Health Care Delivery; Box 13, Folder: Symposium at Golden Clinic.

11 Derickson, 129.

12 Symposium program for Golden Clinic symposium. Fund archives, Series III, Health Care Delivery; Box 13, Folder: Symposium at Golden Clinic.

13 Letter to Kerr from chief of medicine at Harlan Memorial Hospital, 2/22/57. FUNDA, Series III, Health Care Delivery; Box 11, Folder: "Pneumoconiosis Conferences". The name of the chief of medicine has not been included due to restrictions on usage of the Fund archives.
} 
demonstrate to our profession the effectiveness, efficiency, and desirability of our regional system of medicine...to be to chronic pulmonary disease of soft coal workers what the Veterans Administration has been to pulmonary tuberculosis." 14

Local physicians were also eager to learn more about the disease directly from the experts themselves, which the Fund was regularly bringing to America. The experts were often encouraged and impressed by the efforts of local physicians to learn more about the disease and correctly diagnose it in their patients. In 1954, the Fund sponsored the visit of a prominent British radiologist, Dr. Ian McCallum, with an expertise in X-Ray diagnosis of black lung. $\mathrm{He}$ proceeded to make a nationwide tour of Fund clinics, public health clinics and labs, and private clinics. Upon visiting the Golden Clinic in Elkins, he noted that "I spent most of my time with Dr. $[\mathrm{M}]$ who is well-informed about British work on pneumoconiosis of coal miners, and I thought that his approach to the problem here was very honest and that the work of the Clinic was of a high standard." 15 The Monongalia County Medical Society in Morgantown, West Virginia wrote to Dr. Falk requesting Dr. McCallum visit their April meeting to discuss black lung disease with them. ${ }^{16}$

West Virginia physicians were thus recognizing black lung disease in their patients and writing to Dr. Kerr and the Fund about their concerns. One pathologist in Huntington wrote to Dr. Draper about his concerns. In recent years he had begun finding alarming changes in the lungs of miners from the Logan and Beckley coal fields. He wrote that “...now we find that the

14 Letter to Fund medical officers from physicians at Harlan Memorial Hospital, 1/7/58. Fund archives, Series III, Health Care Delivery; Box 11, Folder: "Pneumoconiosis Conferences" 15 Letter from Dr. Ian McCallum to Kerr, 7/16/54. FUNDA, Series III, Healthcare Delivery; Box 12, Folder "Pneumoconiosis Consultants". Per restrictions on usage of the Fund archives, the physician's name in question has not been quoted in full.

16 Letter from president of the Monongalia County Medical Society, 2/26/54. FUNDA, Series III, Healthcare Delivery; Box 12, Folder "Pneumoconiosis Consultants". President's name redacted due to Fund archives restrictions. 
carbon pigment is accompanied by some substance which causes a very definite fibrotic reaction; so much so that we are finding it in practically every lung of every coal miner who has been in the occupation for several years." ${ }^{17}$ While his understanding of the pathophysiology of the disease process was ultimately incorrect, this physician nevertheless was recognizing an alarming disease state in miners and speaking out with his concerns. Elsewhere in Appalachian coalfields, doctors were reaching out for more education. Dr. Kerr wrote to a doctor affiliated with the Tennessee Valley Authority, stating "I have recently heard through mutual friends of your interest in coal workers' pneumoconiosis. It is my understanding that you are concerned about the possible development of this disease because of the use of powdered coal in your operation." 18

The Fund archives also have records of correspondence not just between physicians and the Fund leadership, but between physicians and their physician colleagues. While taking issue with another physician completely discrediting the utility of X-rays as a diagnostic tool in the disease, a physician from Milwaukee wrote to a Fund physician stating that "of course, I agree that soft coal miners develop pneumoconiosis...and I also agree that they may develop disabling pneumoconiosis when the coal dust deposits in the lungs are heavy and when they are associated with severe vesicular emphysema and tuberculosis, both of which are unrelated conditions. I also agree that when a disabling pneumoconiosis in coal miners is found to be real, that miner should be compensated, whether or not these associated conditions are causally related." 19 The Fund received a copy of a correspondence between two physicians, one in Alabama and one in

17 Letter from Huntington pathologist to Draper, 4/20/56. Fund archives Series III, Healthcare Delivery; Box 12, Folder "Pneumoconiosis General". Pathologist's name redacted due to Fund archives restrictions.

18 Letter from Kerr to TVA physician, 10/13/55. Fund archives Series III, Healthcare Delivery; Box 12, Folder

"Pneumoconiosis General". TVA physician's name redacted due to Fund archives restrictions 19 Letter from Milwaukee physician to a physician with the UMWA, 6/14/54. Fund archives, Series III, Healthcare Delivery; Box 12, Folder "Pneumoconiosis General". Names redacted due to Fund archives restrictions 
Cincinnati, discussing the topic in which the physician from Alabama emphatically stated "Pneumoconiosis of soft coal workers has been established as a definite disease entity beyond reasonable doubt both in this country and in Wales." He invited the physician from Ohio to visit him at his exhibit on the topic at the upcoming American Medical Association meeting. ${ }^{20}$

Taken together, these letters, reports, and programs show that there was a strong current of interest in black lung among physicians practicing in mining communities. Separate from Fund activities, they were working to expand their knowledge about the disease process and begin accurately diagnosing it in their patient populations. The Fund, especially Kerr, provided valuable assistance to these physicians. Without the efforts of Kerr and others in the Fund, these physicians would have been unable to meet and directly consult with black lung experts. Many of them also would likely have never heard of the disease, nor would they have received the literature on it that they did. However, the Fund was by no means pushing information onto an unwilling audience. The numerous physicians who requested more information, who held conferences, who wrote to the Fund of their concerns, and who proactively asked to meet with the international experts show a picture of the medical community that is different than what has been portrayed. The initiative these physicians took to understand this disease and care for their patients should not be discredited or overshadowed by the later drama and controversy regarding black lung compensation bills.

While not as robust as that in Great Britain, there was also ongoing American medical research during this time period into the disease. Often this research was being performed by doctors and administrators from mining areas. In 1957, the AMA Archives of Industrial Health published a series of articles written on the subject. In this series, the chief of the Branch of 
Health Research of the Bureau of Mines (based out of Pittsburgh) at the Department of the Interior wrote about the necessity of considering new dust control measures in coal mines. Lawrence Berger's article was presented at the Golden Clinic Second Symposium on Coal Workers Pneumoconiosis held in Elkins, West Virginia in October of $1955 .{ }^{21}$ Included in this article is discussion amongst attendees and the author held at this Symposium, in which it was clearly stated that the disease that would become known as black lung was a distinct disease process, with an identical presentation in the United States as in Great Britain. This statement was further supported by articles written by Dr. J.E. Martin and Dr. David Waterman, both of whom were involved in direct patient care with coal miners suffering from the disease. ${ }^{22}$ That same year, another study of coal workers in the Ohio River Valley was conducted which also concluded that there existed a disease process, distinct from silicosis, in coal miners in the US, the presentation of which was identical to that in Great Britain. ${ }^{23}$ This was published in one of the nation's most prestigious and widely-read medical journals, the Journal of the American Medical Association. The doctors who cared for miners were not just interested in learning about the disease, but were beginning to make their own investigations into the topic.

The medical establishment during this time period was also not as unwilling to accept the disease as has been portrayed. Historians, like Derickson, looking at the period between 1960 and the culmination of the black lung battle in 1969 have likely picked up on this conflict in their reading of events. Looking only at this period, it is not unreasonable to conclude that the medical establishment was firmly against the interests of strong labor movements like the UMWA and

21 Lawrence E. Berger, "Some Considerations on Dust Control in Coal Mining", AMA Archives of Industrial Health Vol 15, no. 6, 499-505.

22 J.E. Martin JR, "Breathless Coal Workers as Seen at the Golden Clinic", AMA Archives of Industrial Health Vol 15, no.6, 494-497 and David H. Waterman, "Pulmonary Disease Problems in 2140 Admissions of Soft Coal Workers, AMA Archives of Industrial Health Vol 15, no. 6, 477-486. 23 Milton D. Levine and Murray B. Hunter, "Clinical Study of Pneumoconiosis of Coal Workers in Ohio River Valley", The Journal of the American Medical Association, Vol 163, no. 11-3. 
BLA. However, interpreting this period in the greater context of the black lung issue from the 1940s on provides a different conclusion. At worst, evidence from the era before the 1968-1970 climax of the black lung fight shows that the medical community was preoccupied with other concerns (such as education of new physicians and a changing healthcare payment structure) and took an ambivalent attitude toward the disease.

Before the Fund began their recruitment of international experts and physicians held their own conferences, the officers of the WVSMA and the editors of the $W V M J$ believed it important to include coverage of black lung and miner respiratory diseases. In 1949, after publishing an article on the disease process that would later come to be known as black lung, the editors of the journal stated "The problem of anthracosilicosis is becoming more and more prominent as industrial medicine progresses, and, certainly so far as West Virginia is concerned, the welfare program of the United Mine Workers has accentuated it very materially...accordingly, our publication committee has decided to issue an anthracosilicosis number in November." ${ }^{24}$ Their coverage of the disease does fall victim to the confusion in the American medical community at the time about whether black lung was distinct from silicosis - hence the blanket term of "anthracosilicosis." Still, less than a decade after the British compensation law had passed the medical establishment in West Virginia was recognizing the existence of this disease, and crediting the Fund for bringing awareness to it.

The promised issue devoted to the anthracosilicosis was published in November of that year, and included three articles covering symptoms, diagnostic findings, and the determination of disability in the miner afflicted with the condition. Unable to include their final planned article

24 Burgess Gordon, Hurley L Motley, Peter A. Theodos, and Leonard P. Lang, "Anthracosilicosis and Its Symptomatic Treatment”, West Virginia Medical Journal (hereafter WVMJ) 45, no. 6 (1949), 125-132. Publication committee comments, WVMJ 45, no. 7 (1949), 179. 
of the November issue due to reproduction issues, in January of 1950 they concluded the series with a lengthy article on pulmonary function studies in bituminous coal miners. ${ }^{25}$ All of the papers covered had been presented before the West Virginia chapter of the American College of Chest Physicians (ACCP) at their conference in May, 1949. This shows that not only was the WVSMA openly promoting coverage of the disease, but the state chapter of the ACCP was also giving speaking time to physicians who were researching the disease.

Early coverage of black lung did not end with this special issue. The $W V M J$ published about "The Silicosis Problem" in January of $1951 .{ }^{26}$ The following year, Dr. N.H. Dyer, the State Director of Health for West Virginia, wrote about the incidence of cancer related to mining in West Virginia, during which he voiced frustrations with labor, the coal operators, and other physicians for not undertaking rigorous study of occupational exposures in the mining population and the resultant risk of cancer. ${ }^{27}$ Again, this coverage of the issue is not consistent with the coverage of a medical community unwilling or hostile to the recognition of black lung. If the medical establishment had been firmly against the recognition of the disease or wholly unwilling to learn more about occupational lung disease, they would not have accepted and published articles on the topic, nor would they have devoted precious conference time to the matter.

After this initial strong showing of interest, the medical establishment locally and nationally was generally not interested in the topic of black lung. The WVSMA became heavily dedicated in the emerging issues of national insurance and changing methods of payment for the delivery of medical care, as well as the success of the West Virginia University Medical Center. The West Virginia Academy of Family Physicians invited Dr. Donald Rasmussen to speak at its

25 Hurley L. Motley, "Pulmonary Function Studies in Bituminous Coal Miners", WVMJ 46, no. 1, 8-23.

26 Burgess Gordon, “The Silicosis Problem”, $W V M J$ Vol 47, no. 1, 1-8.

27 N.H. Dyer, "Cancer As Related to the Mining Industry in West Virginia”, WVMJ Vol 48, no. 7, $187-189$. 
annual Scientific Assembly on the topic of black lung, but otherwise its attention was invested in the development of Family Practice residency programs in the state. ${ }^{28}$ The efforts of the Fund and local physicians to nudge the medical community to action had at least stirred the US Public Health Service to launch a survey into the disease in $1963 .{ }^{29}$ Compensation for disabled miners was awarded in a small handful of states. Alabama led the nation in mandating compensability for the disease in 1951; Virginia followed in 1958 and by early 1968 these states and Pennsylvania had required compensation for black lung as a disease process distinct from silicosis. ${ }^{30}$ Despite the enthusiasm of West Virginia doctors and the West Virginia medical community only a decade before, West Virginia lagged behind in compensating miners for black lung. The BLA and three West Virginia doctors sought to change that.

The Physicians Committee for Miners' Health and Safety preceded the formation of the BLA. Initially, the only physician with widespread activism in the West Virginia coal fields was Dr. Buff. He had already been active in anti-poverty and social justice campaigns during the period of Appalachian activism initiated by the Great Society and War on Poverty reforms. In 1968, he toured the coal fields, meeting with miners and informing them of the existence of black lung and encouraging them to fight for compensation. He had a long list of organizations he blamed for the disease and lack of compensation for it, ranging from West Virginia University (WVU) to the UMWA as well as many of his physician colleagues. He was also the person who popularized the term "black lung." ${ }^{31}$ Prior to this, it had been referred to by its medical terms: either coalworkers pneumoconiosis, anthracosilicosis, or miners' asthma. Later that year, Dr.

28 Program of The Twelfth Annual Scientific Assembly, May 15-17, 1964. Records of the West Virginia Academy of Family Physicians. 29 Derickson, 134. 30 Derickson, 124, 138.

31 Derickson, 147. 
Buff formed the Physicians Committee for Miners' Health and Safety when he connected with Dr. Rasmussen and Dr. Hawey Wells, both of whom had been participating in black lung research and who were concerned about the prevalence of the disease in West Virginia.

Local media noticed the physicians and their concerns. Their educational efforts bore fruit, and the BLA was formed in January 1969. From here, things moved quickly. Having galvanized thousands of miners in the West Virginia coal fields into action, the three physicians now had the attention of the government and the coal operators in addition to that of the media. The West Virginia medical establishment renewed its interest in the disease. The reaction was not outright hostile, but certain elements within the medical community did oppose the efforts of Buff and his companions. In January 1969, shortly after the BLA was formed, the Cabell County Medical Society listened to a presentation by Dr. Rowland Burns on the topic of black lung. As Burns later reported to the Beckley Post-Herald in Beckley, West Virginia, he "could not as a conscientious physician arrive at the same conclusions which Dr. Rasmussen reported after the evaluation of his own data." 32 The Society, after listening to his presentation, proceeded to pass a resolution condemning the activists. After laying out its belief that "simple uncomplicated and uninfected Coal Worker's Pneumoconiosis is a condition compatible with reasonable health and not associated with significant disabling disease," it turned its attention to the physician activists, stating that "it does not endorse such behavior and that the function of the physician and organized medicine is not served by alarming appeals based upon evidence upon to serious question of its validity." 33

32 "Physician Refutes Backers of Black lungBlack lungBlack lung Legislation", Beckley Post-Herald, January 17, 1969.

33 Resolution of the Cabell County Medical Society, Fund archives Series III, Healthcare Delivery, Box 12; Folder: "Pneumoconiosis General". 
The Kanawha County Medical Society also passed a resolution that year reprimanding Rasmussen, Buff, and Wells, stating that they would not "condone the activities of those in the medical profession who have unduly alarmed and incited a number of those employed in the coal industry without first having presented scientific documentation of their findings." ${ }^{34}$ The motivations of the Kanawha County Medical Society (KCMS) are unclear, but Dr. Rasmussen later stated that Dr. Burns routinely worked for the coal companies which may explain his stance and his influence in Cabell County. Interestingly, two months before their resolution, the KCMS had heard a lecture on black lung presented by Dr. Charles Andrews, the Provost of Health Sciences at WVU. ${ }^{35}$ In a later interview with the Beckley Post-Herald, Dr. Andrews emphasized the importance of X-ray in diagnosing the disease but also pointed out that a miner could have other serious diseases, such as cardiac disease, separate from black lung and linked to lifestyle choices such as smoking and poor diet. ${ }^{36}$ If Dr. Andrews discussed a similar viewpoint with the KCMS, they may have concluded that the alarm about black lung was overblown and other, more serious diseases existed requiring their attention.

Acknowledging the growing tension in the state over the matter, the state governing council of the WVSMA released an official statement following a meeting held January 26, 1969. The statement came in March and stated that it "recognizes the responsibility and privileges of any physician to participation in such matters of general and professional interest, provided such participation and discussion is conducted with courtesy and objectivity." It went on to state that it "earnestly recommends to the legislative bodies of this State the appointment of a panel of experts in the field of pulmonary diseases to conduct a thorough objective study of the

34 "Medics Rap Rasmussen, Buff, Wells", Beckley Post-Herald, January 25, 1969. 35 "County Societies", $W V M J$ 65, no. 1, xvi.

36 “Determining 'Black lung' Disability Is Difficult”, Beckley Post-Herald, January 19, 1969. 
pathologic conditions under discussion, and to report their findings and recommendations to the Governor and the Legislature within a reasonable period of time." ${ }^{37}$ This was far from a ringing endorsement of the physician activists and the issue at hand, but it was not an outright condemnation as the county medical societies mentioned above had undertaken. While it did ignore the established medical literature on the disease and the "objective study" which had already been undertaken by multiple groups, it acknowledged it as a serious condition requiring further study. No other county medical societies followed Kanawha and Cabell County's lead.

The members of Physicians for Miners' Health and Safety openly accused the medical community and various doctors of not understanding the disease process as well as being in league with the coal operators. In response to Dr. Burns's comments that month, Dr. Rasmussen stated "it is well known that examinations of miners by Dr. Burns are made for use in defense of coal operators against miners' claims," and further reported that "the operators have hired a research concern to gather physicians' opinions on the disease and disabling effects, offering to pay each physician $\$ 50$ for his answers to six questions. ${ }^{{ }^{38}}$ More well-publicized clashes happened between the physician activists and other members of the medical community. In April, Dr. Buff and Dr. Rasmussen directly contradicted the opinion of William H. Anderson, a University of Louisville physician, on the subject of dust abatement in the mines. Speaking before a House Labor subcommittee, they asserted coal dust must be decreased in the mines. Dr. Anderson testified that "the control of coal dust disease is not the answer" and stated only $17 \%$ of breathless miners actually had black lung whereas the rest had other, non-occupational lung diseases..$^{39}$ It is important to note that Dr. Anderson and his research group, the Spindletop

37 "Winter Meeting of the Council in Charleston on Jan. 26", WVMJ 65, no. 3, 90.

38 "State 100 Years Behind on Protection Laws for Miners, Charleston Doctor Says", Beckley Register and PostHerald, January 18, 1969.

39 "House Airs 'Black lung' Buff, Others Clash at Hearing.", Charleston Daily Mail, April 16, 1969. 
Research Group, had been hired by the West Virginia Coal Association in January of that year to testify on its behalf regarding black lung. ${ }^{40}$

Nationally, the media and scientific journals continued reporting that the American medical community was slow at best, and actively resistant at worst, to acknowledge black lung. A 1971 Science article, for instance, it reports as fact that "it had been widely held in official medical circles that miners did not suffer from lung disease in any greater proportion than nonminers." It goes on to state that Pennsylvania had far more miners qualifying for black lung benefits not because of true disease prevalence, but because "its medical professionals were not dominated by the coal industry." 41 This demonstrates that by 1971 , the narrative had been established of a reluctant medical community, often controlled by the coal companies, that had been shirking its duty to care for its patients.

The coal operators, in their reaction to the 1969 movement, further promoted the idea of widespread medical resistance to black lung recognition. The coal operators responded to the BLA movement with characteristic resistance and, at times, hyperbole to rival that of the flamboyant Dr. Buff. In a statement covered by the Morgantown Dominion newspaper, the West Virginia Coal Association compared itself to a "shivering sparrow" that had "poorly wintered the years when it lost almost all of its steam locomotive market and almost all of its home heating market" and warned that "the cornerstone of West Virginia's economy is being seriously threatened because of a lack of understanding and misrepresentation of fact." 42 Later that year, having lost the battle for black lung compensation and facing new changes to the law at the state and federal level, the Association took out a large ad in the Charleston Daily Mail. The ad has a

40 The Associated Press, “Ky. Firm Hired for black lung Investigation”, Charleston Daily Mail, January $21,1969$. 41 Joe Pichirallo, "Black lung: Dispute about Diagnosis of Miners' Ailment”, Science 174, No. 4005, $132-134$. 42 Martin, Ray. "Miners' black lung —What Is it? Legislators to Hear Arguments Today", The Dominion News, Morgantown, WV, February 11, 1969. 
picture of a coal miner, with large text above and below the picture stating "Joe works in a coal mine. Black lung comes from working in a coal mine. Therefore, Joe has Black lung. Logically, it sounds good. Medically, it's full of hot air." It then goes on to claim that expanding black lung compensation and loosening the requirements for recognition would "fly in the face of resolutions of pulmonary specialists and the West Virginia State Medical Association." ${ }^{43}$ No such resolutions were passed or recorded in the $W V M J$ during this time period. Such statements and actions, combined with the known and alleged cooperation of certain physicians with the coal operators, served to reinforce the notion that Drs. Buff, Rasmussen, and Wells were lone crusading activists fighting an entire industry as well as the medical establishment.

The actions of the medical community later in 1969 and beyond were not the actions of a community in thrall to a corrupt industry. Following passage of the WV black lung law in March 1969, county and state medical societies and organizations began hosting talks and conferences on black lung disease. In April, the Mercer County Medical society hosted the president of the WVSMA who discussed the new black lung legislation with its members. ${ }^{44}$ In September the WVMJ dedicated space in its meetings section to promote a black lung conference in Kentucky. ${ }^{45}$ In November, the Monongalia County Medical Society hosted a WVU physician to discuss "Coal Workers and Pneumoconiosis." ${ }^{46}$ In January 1970, the topic of the Third Annual MidWinter Conference on Chest Diseases was black lung. Sponsored by the WVSMA, the WVU Medical Center, and the West Virginia Thoracic Society, this symposium was a broad conference covering pathology, epidemiology, and case presentations. ${ }^{47}$ It was very well-

43 Ad in Charleston Daily Mail, Charleston, WV, July $8^{\text {th }}, 1969$.

44 "County Societies", $W V M J 65$, no. 6, xxvii.

45 "Black lung Conference in Kentucky", $W V M J$ 65, no. 9, 313.

46 "County Societies", $W V M J$ 65, no. 11, xxii.

47 "Pneumoconiosis Course Set for Charleston, Jan. 25”, WVMJ 65, no. 12, 433. 
attended, with more than 100 physicians present for the symposium. ${ }^{48}$ In Elkins in June of 1970, the Tygart Valley Medical Society's annual educational meeting focused on the disease, with a panel presentation on "soft coal workers pneumoconiosis." 49 There were no meetings, at the state or county levels, promoting the theory of non-existence of black lung disease.

This enthusiasm and embrace of widespread educational activities on the topic of black lung, like the educational efforts of the 1950s, show that the medical community was not as hostile towards black lung as has been previously written. While it lagged seriously behind the British medical community in recognition of the disease, there is no consistent evidence for a widespread campaign of collusion with the coal operators. If the community had been as deeply opposed to the passage of black lung laws as contemporary sources and current historiography suggests, one would not expect such rapid motion on the part of the medical community in West Virginia to educate itself about the disease. The AMA and WVSMA had never been organizations reluctant to lobby and campaign against legislation they felt harmed their constituents or their patients. They would not have changed this now. Furthermore, the alliance of the physician activists was not as harmonious or unified as one would believe. By mid-1969, a rift had already developed in the group. Dr. Buff accused Dr. Wells of using the black lung fight for political gain after Wells announced his candidacy for president of the WV Young Democrats. ${ }^{50}$ Further divisions in the group occurred when Drs. Rasmussen and Wells publicly endorsed Jock Yablonski in his campaign for the UMWA presidency, whereas Buff refused to make any endorsements but this time stated he had "no objections" if the others wished to do so. ${ }^{51}$

48 "More than 100 Persons Attend Black lung Conference", WVMJ 66, no. 3, 104.

49 "Tygart's Valley Medical Society Lists PG Session", WVMJ 66, no. 6, 211.

50 Ray Martin, "Wells Seeks YD Post, Flays Party Leaders”, Morgantown Dominion News, June 20, 1969.

51 "Doctors Endorse Jock", Morgantown Dominion News, August 1, 1969. 
Individual physicians, clinics, hospitals, and the medical community had been actively involved in the drive for black lung awareness and education since its earliest days. The UMWA Welfare and Retirement Fund provided a key service by coordinating domestic visits by international black lung experts and by disseminating medical literature to interested parties around the country. It also encouraged significant internal educational efforts with its staff and medical officers. The Fund was not forcing education on an unwilling group, however. Numerous groups made efforts to host their own black lung symposiums, and numerous individual physicians actively engaged in educational activities to further their own knowledge about the disease process. It is possible that the surviving records of these activities in the Fund archives are victim of sampling bias on behalf of the Fund medical officers, and that the Fund officers chose to discard correspondence from physicians who were uninterested or hostile to their activities. This seems unlikely, however. Dr. Kerr and his colleagues at the Fund were conscientious and thorough in their efforts to expand awareness of black lung among physicians in coal mining communities. It would be unusual and ill-advised to ignore resistance to their activities, because to do so would only make their work more difficult by not addressing key obstacles to their work.

The Fund officers had no direct involvement with the activities of the WVSMA nor publications in the $W V M J$. Because of its scope of topics, the $W V M J$ provides an excellent window into the medical community in West Virginia during this time period, both at the level of the medical establishment and at the level of the individual physicians who constituted its membership. Then, as now, physicians had limited time to engage in educational activities. As a result, physicians chose educational activities that would be of the highest utility and interest to them. When one has only a limited amount of time to pursue continuing medical education after 
the demands of a busy day in the clinic or the hospital, one does not spend it on topics perceived to be of little interest or clinical significance. As the $W V M J$ noted in 1956 on the immense burden of literature and education facing the average physician, "That which must be read somehow gets read; much that should be read does not." ${ }^{, 52}$ Publication space in the $W V M J$ was therefore a premium venue for disseminating knowledge, as were the meetings and conventions of various physician groups. Physicians considered the topic to be "that which must be read." The consistent willingness of the $W V M J$ to publish articles on black lung and the Fund shows that the WVSMA believed the topic to be important to its members and the Fund an important member of the healthcare system in West Virginia. Dedicating an entire issue to a single topic, as the $W V M J$ did in November of 1949 for anthracosilicosis, is a dramatic show of concern and interest in a topic, which rarely happened during this time period. Likewise, the consistent willingness of the county medical societies to welcome black lung education after passage of the compensation laws in 1969 shows a rapid acceptance of the legislation. The county medical societies were not holding talks on fighting black lung legislation, and the WVSMA was not rallying its members to protest the legislation the way it had other topics such as the Forand Bill. Instead, medical societies — both county and specialty-specific_-were encouraging their members to obtain more knowledge about a process that was affecting a large portion of the state's population.

These activities were quiet activities, and their insular nature, confined to a highly specialized profession, meant that the general population did not know about them. The $W V M J$ is not a publication read widely by many people outside of the medical profession, and this was surely the case then. The internal correspondence and records of the Fund were also not available

52 “Reading Time for Physicians Two to Four Hours Daily", WVMJ 52, no. 5, xlviii. 
to the public. As a result, the actions of the parties involved did not attain the exposure in the public eye that the actions of other figures in the black lung fight did. The WVSMA was not crumbling up the blackened lungs of deceased miners or telling community buildings full of living miners they were all going to die from black lung, as Dr. Buff was wont to do. The WVSMA and the average physician were also not responsible for galvanizing a large population of rank-and-file miners, dissatisfied with their union on other matters as well, to independently fight for recognition of their concerns. It is only natural, therefore, that the contemporary narrative focuses mainly on the activist physicians and not the large medical community to which they belonged. Black-and-white stories of good versus evil, of the underdog versus the powerful and corrupt boss, also sell much better than stories of complex shades of grey, without clear definitions. Appalachia during this time period was also primed to hear stories of the average citizen fighting back against the coal companies as concurrent showdowns regarding voting rights and strip mining were playing out across the region.

This is not to say that the medical community was completely uniform in its acceptance of the disease state and the need for compensation. The actions of the Kanawha County Medical Society and the Cabell County Medical Society in 1969 demonstrate this. Internal dispute regarding the prevalence of the disease, the importance of dust abatement as a preventive measure, and the potential disability of the disease continued within the medical profession, although to a lesser extent than was reported then and now. In many of the cases of the fiercest opposition, there existed reasons for bias, such as the purported employment of Dr. Roland Burns as a coal company physician and the confirmed consultation activities of Dr. William Anderson. There exists no evidence for widespread bias in the medical profession, as claimed by 
individuals such as Buff, and which is directly contradicted by the coverage of the profession in the $W V M J$.

Other black lung historical researchers, Derickson among them, have examined the Fund archives and have also reviewed the various articles published in the $W V M J$. They have also examined newspaper reports from the time period. However, these researchers too easily overlooked the efforts of the medical community to educate itself on the matter and bring awareness to the matter. They also appeared to approach the topic with an existing confirmation bias: having already decided that the average mining community physician and his medical community was indifferent or hostile to black lung awareness, they interpreted the primary sources to support that assertion. This was likely due to the fact that even contemporary primary sources from the late 60 s and early 70 s were reporting this as fact. Finally, they lacked an important context about the nature of the medical profession and its priorities, namely the inferences one can make about the profession's attitudes towards a topic based on the time it dedicates to it in its educational activities.

Reading the $W V M J$ with this context in place and approaching the primary sources holistically, with an open perspective, tells a different story than has been previously promoted. The black-and-white story of black lung recognition in the United States shifts from a story of renegade physicians and miners against an uncaring medical profession and union. A more nuanced story emerges instead. As in so many areas in life, there were no absolute heroes and absolute villains during the black lung fight, and an entire profession cannot be discredited because of the actions of a few. The medical community in mining areas was overall genuinely interested in recognizing this deadly disease from an early point, and eager to diagnose it and 
assist miners in obtaining benefits once compensation laws were passed. It was not entirely the entity wracked with "ill-informed complacency" it has been accused of being. ${ }^{53}$

53 Derickson, xii. 


\section{Conclusion}

Black lung is a terrible disease that has appeared in every coal mining community around the world. It is a constant threat to miners, like roof falls and explosions. Despite this universal threat, different countries have approached the topic very differently. Some countries, like Great Britain, saw a union of labor, medicine, and government to ensure protections and compensation for miners. Others, like America, required massive demonstrations and numerous deaths to achieve the same interventions. This work has examined these two countries and their approaches to the topic by studying the roles of labor and medicine in their countries and communities. These same roles and actions not just explain the differences in black lung recognition, but also the fundamental differences in each country's healthcare system. Therefore, understanding the intricacies of black lung in each region allows one to understand the underpinnings and foundations for each country's healthcare system today.

This work, while investigating the topic of black lung from a newly international and comparative perspective, is by no means the final statement on the matter. Several important gaps exist, especially in American historiography, that could further illuminate the complexities of this topic. First, no American work has examined, in depth, the perception of the miner and his body in America. Some inferences can be made by examining periodicals and the medical literature, but there is no American counterpart to works such as Disability in Industrial Britain. We very clearly know how organized medicine viewed organized labor and the UMWA, for the historical record and archives of each group are replete with correspondence, resolutions, and condemnations traded between the groups. However, much work remains to be done in the examination of how medicine viewed the miner and the miner's body. Was the American miner upheld as a symbol of American industrial might? Was the miner's body of material concern to 
the American public as a whole, and was the miner's life romanticized or derided? Significant research into the US popular press and culture as well as a detailed and focused study of the medical literature is necessary to answer these questions.

Unfortunately, due to the COVID-19 pandemic, archival research in Wales was not possible as planned. The secondary literature and available digitized archives have provided an enormous wealth of information. However, it is reasonable to believe that the archival study of the South Wales Coalfield Collection in Swansea could augment or even change the conclusions and research studied here. Specifically, the similarities and differences between West Virginia and Wales could best be explored by accessing the primary archival sources contained in Wales, which are not available in a digitized format. Of special interest would be further documents pertaining to the Welsh medical community, especially focusing on physicians' relationships with their miner patients and the dissemination of medical knowledge.

There are also areas of identity that can be explored. McIvor and Johnston devote a section of their work to examining how the disease of black lung is interpreted by miners and how it affects miners' experience of masculinity. A similar examination of American miner gender roles and the effect of health on these roles is certainly possible. An examination of West Virginia miner gender roles would be a fascinating contribution to the large field of Women's and Gender Studies. There has also not been any significant study on how women miners experience black lung, whether culturally or medically. While they are certainly a minority of miners in each country, they experienced the risks of coal mining as much as any male miner did. It would be interesting to see how their gender identity and their biological physiology impacted these experiences. 
Finally, it has been difficult to understand just how much communication existed between organized labor and organized medicine in the two countries. We know that the leaders of miners' unions around the world were invited to UMWA conferences, and there was an international conference as well. However, with the exception of Fund officials, was there a great deal of transatlantic communication about black lung? The same is true for medical literature. To what extent did British journals such as the BJIM penetrate the coalfields? How much genuine ignorance about British black lung and its implications for their own communities could American coalfield doctors claim? This is another importance piece in understanding the motivations as well as the successes and failures of medicine in each region.

The study of the history of black lung has additional applications. Alan Derickson described black lung as a "public health disaster" in the United States. McIvor and Johnston also considered the delay in recognizing and containing British black lung a failing in public health. They are correct. The disease of black lung has affected hundreds of thousands of miners and their families and as a result has affected the health status of entire communities. Public health leaders should study this history and learn from its mistakes to prevent future occupational health disasters. Black lung certainly isn't going away, and in fact it is resurging in several central Appalachian communities. ${ }^{1}$ New occupational dust diseases have emerged. ${ }^{2}$ However, in many ways the relationships between American organized medicine and organized labor have not fundamentally changed. While we now have bodies such as the National Institute for Occupational Safety and Health or the Occupational Safety and Health Administration, for many

\footnotetext{
${ }^{1}$ Howard Berkes, “Advanced Black Lung Cases Surge in Appalachia," National Public Radio, December 15, 2016, https://www.npr.org/2016/12/15/505577680/advanced-black-lung-cases-surge-in-appalachia

${ }^{2}$ Nell Greenfield-Boyce, “'It's Going to get Worse': How U.S. Countertop Workers Started Getting Sick”, National Public Radio, November 21, 2019, https://www.npr.org/sections/health-shots/2019/11/21/777268528/it-s-going-toget-worse-how-u-s-countertop-workers-started-getting-sick
} 
physicians occupational health and safety is an afterthought, reserved for those few who are actually board-certified occupational medicine specialists.

The relationships between British labor and medicine and American labor and medicine were drastically different by World War II, and these differences persisted. The spirit of collaboration between medicine, miners, and the Labour Party in Britain directly influenced the development of the National Health Service. The antipathy between organized medicine and organized labor in America, however, only increased throughout the post-War period, ending any hopes of a nationalized health service in the United States. Black lung recognition is an important case study of these relationships. By studying black lung one can gain a greater appreciation of why the healthcare systems of the two countries diverge. This relationship and topic is worth its own focused research and is an important part of the history of medicine and labor in each country.

Black lung can also teach us about our response to COVID-19. Responding successfully to a pandemic requires collaboration and cooperation among all levels of society. It also requires a stable healthcare system and public health infrastructure. The American healthcare system, capitalist and profit-centered at its core, was not prepared for a new reality in which the safest thing to do has been to sell less and spend less. For decades, it has been focused on increasing profit margins which has led to such problems as the critical PPE shortage. Pandemics also require citizens and bodies to care for others in a collectivist spirit. Just as the relationships of British medicine and labor allowed both parties to work together to achieve a public health goal, so has this same spirit of collaboration and collectivism allowed Britain to respond more successfully to the pandemic. In America, however, medicine has long been separated from labor and the notion of working together for a common social good is, in practice, an alien idea. There 
remains a fundamental disconnect between organized medicine and the lived experience of the working public. These same bodies, and these same relationships, failed to recognize and intervene in black lung for decades. Now, as the U.S. death toll of COVID19 escalates higher and higher, how can we look back and have expected any other outcome? How can we have expected our organized medicine bodies, long supporting a capitalist healthcare system and long at odds with the working public, to have the power to implement the life-saving measures which were necessary? 


\section{Bibliography}

\section{Primary Sources}

\section{Memoirs:}

Coombes, BL. These Poor Hands: The Autobiography of a Miner Working in South Wales. (London: V. Gollancz, 1939)

Sharp, Roland. Roland Sharp, Country Doctor: Memories of a Life Well Lived. (Dunmoore: Pocahontas Communications Cooperative, 2008)

Wharton, May Cravath. Doctor Woman of the Cumberlands. (Nashville: The Parthenon Press, 1972)

\section{Archives:}

War Cabinet Files, National Archives of the United Kingdom, Digital collection.

Records of the West Virginia Academy of Family Physician, Hurricane, West Virginia

Archives of the United Mine Workers of American Health and Retirement Fund. West Virginia and Regional History Center. West Virginia University. Morgantown, WV.

\section{Medical literature:}

The Lancet, Volume 1

The British Medical Journal, Volume 1

The British Journal of Industrial Medicine, Vols. 1-9.

The West Virginia Medical Journal, Volumes 45-48, 52, 56, 65, 66

JAMA Archives of Industrial Health, Volume 15

The Journal of the American Medical Association, Volumes 163, 319

\section{Newspapers}

Charleston Daily Mail, Charleston. West Virginia

Morgantown Dominion News. Morgantown, West Virginia

Beckley Register and Post-Herald. Beckley, West Virginia 


\section{Other}

Berkes, Howard. "Advanced Black Lung Cases Surge in Appalachia." National Public Radio. December 15, 2016. https://www.npr.org/2016/12/15/505577680/advanced-black-lung-casessurge-in-appalachia

Greenfield-Boyce, Nell. "'It's Going to get Worse': How U.S. Countertop Workers Started Getting Sick.” National Public Radio. November 21, 2019.

https://www.npr.org/sections/health-shots/2019/11/21/777268528/it-s-going-to-get-worsehow-u-s-countertop-workers-started-getting-sick

Cronin, AJ. The Citadel. RosettaBooks: 2015. Kindle.

\section{Secondary Sources}

Barney, Sandra. Authorized to Heal: Gender, Class, and the Transformation of Medicine in Appalachia, 1880-1930, (Chapel Hill: The University of North Carolina Press, 2000)

Bohata, Kristi; Jones, Alexandra; Mantin, Mike; and Steven Thompson. Disability in industrial Britain: a cultural and literary history of impairment in the coal industry, 1880-1948.

(Manchester: Manchester University Press, 2020)

Bonea, Amelia; Dickson, Melissa; Shuttlesworth, Sally; and Walls, Jennifer. Anxious Times: Medicine and Modernity in Nineteenth Century Britain. (Pittsburgh: University of Pittsburgh Press, 2019)

Derickson, Alan. Black Lung: Anatomy of a Public Health Disaster,.(Ithaca: University of Cornell Press, 1998)

Eller, Ronald. Miners, Millhands, and Mountainers: Industrialization of the Appalachian South, 1880-1970. (Knoxville: University of Tennesee Press, 1982)

Eller, Ronald. Uneven Ground: Appalachia Since 1945. (Lexington: University Press of Kentucky, 2008)

Donaldson, K; Wallace, WA; and C Henry, C "James Craufurd Gregory, 19 ${ }^{\text {th }}$ century Scottish physicians, and the link between occupation as a coal miner and lung disease". Journal of the Royal College of Physicians of Edinburgh no. 47 (2017): 296-302.

Goan, Melanie Beals. Mary Breckinridge: The Frontier Nursing Service and Real Health in Appalachia. (Chapel Hill: The University of North Carolina Press, 2008)

Gochfeld, Michael. "Occupational Medicine Practice in the United States since the Industrial Revolution," Journal of Occupational and Environmental Medicine 47, no. 2 (2005): 115-131

Layborn, Keith. Fifty Key Figures in Twentieth Century British Politics. (London: Taylor and Francis Group, 2002) 
Lee, W.R. "Emergence of occupational medicine in Victorian Times,” BJIM 30 (1973): 118-124.

Le, Tao; Bhushan, Vikas; and Vasan, Neil. First Aid for the USMLE Step 1: 2010. (New York: McGraw Hill Medical, 2010).

McIvor, Arthur and Ronald Johnston. Miners' Lung: A History of Dust Disease in British Coal Mining. (London: Ashgate Publishing, 2007)

Mulcahy, Richard. A social contract for the coal fields: the rise and fall of the United Mine Workers of America Welfare and Retirement Fund.

Numbers, Ronald L. "The Third Party: Health Insurance in America," in Morris J. Vogel and Charles E. Rosenberg (eds), The Therapeutic Revolution: Essays in the Social History of American Medicine (University of Pennsylvania Press, 1979).

Perret, Jennifer L., Brian Plush, Philippe Lachapelle, Timothy S.c. Hinks, Clare Walter, Philip Clarke, Louis Irving, Pat Brady, Shyamali C. Dharmage, and Alastair Stewart. "Coal Mine Dust Lung Disease in the Modern Era." Respirology 22, no. 4 (2017): 662-70.

Pichirallo, Joe. "Black Lung: Dispute about Diagnosis of Miners' Ailment". Science 174, No. $4005,132-134$

Rosenberg, Charles E. Our Present Complaint: American medicine, then and now. (Baltimore: Johns Hopkins University Press, 2007)

Thomas, Jerry Bruce. Appalachian Reawakening: West Virginia and the Perils of the New Machine Age, 1945-1972. (Morgantown: West Virginia University Press, 2010)

Thomas, Joseph M. "Peculiar Soil: Mining the Early American Imagination," Early American Literature 27, no. 3 (1992): 151-169.

Thompson, Stephen. “A Proletarian Public Sphere: Working-Class Provision of Medical Services and Care in South Wales" in Anne Borsay editor, Medicine in Wales 1800-2000: Public service or private commodity? (Cardiff: University of Wales Press, 2003)

Thompson, Stephen. "Paying the Piper and calling the tune?: Complaints against doctors in workers' medical schemes in the South Wales coalfields" in Jonathan Reinarz \& Rebecca Wynter (eds), Complaints, Controversies and Grievances in Medicine : Historical and Social Science Perspectives (London: Taylor and Francis, 2019)

Turner, David. M and Blackie, Daniel. Disability in the Industrial Revolution: Physical impairment in British coalmining, 1780-1880. (Manchester: Manchest University Press, 2018)

Williams, Chris. Capitalism, Community, and Conflict: The South Wales Coalfield, 1898-1947. (Cardiff: University of Wales Press, 1998) 
Williams, Chris. Democratic Rhondda: Politics and Society, 1885-1951. (Cardiff: University of Wales Press, 1996)

The Labour Party in Wales: 1900-2000, edited by Duncan Tanner, Chris Williams, and Deian Hopkin. (Cardiff: University of Wales Press, 2000) 